\title{
Basement membrane components are key players in specialized extracellular matrices
}

\author{
Jenny Kruegel $\cdot$ Nicolai Miosge
}

Received: 19 January 2010/Revised: 17 March 2010/Accepted: 24 March 2010/Published online: 29 April 2010

(c) The Author(s) 2010. This article is published with open access at Springerlink.com

\begin{abstract}
More than three decades ago, basement membranes (BMs) were described as membrane-like structures capable of isolating a cell from and connecting a cell to its environment. Since this time, it has been revealed that BMs are specialized extracellular matrices (sECMs) with unique components that support important functions including differentiation, proliferation, migration, and chemotaxis of cells during development. The composition of these sECM is as unique as the tissues to which they are localized, opening the possibility that such matrices can fulfill distinct functions. Changes in BM composition play significant roles in facilitating the development of various diseases. Furthermore, tissues have to provide SECM for their stem cells during development and for their adult life. Here, we briefly review the latest research on these unique sECM and their components with a special emphasis on embryonic and adult stem cells and their niches.
\end{abstract}

Keywords Basement membrane - Stem cell niche · Epithelial mesenchymal transition $\cdot$ Cancer $\cdot$ Review

\section{Introduction}

The extracellular matrix (ECM) provides a chemical and mechanical structure, which is essential for development and for responses to (patho)-physiological signals [1]. Differentiation and cell fate decisions are controlled by their surrounding microenvironment of which the ECM is

J. Kruegel $\cdot$ N. Miosge $(\square)$

Tissue Regeneration Work Group,

Department of Prosthodontics, Georg August University,

Robert-Koch-Str. 40, 37075 Göttingen, Germany

e-mail: nmiosge@gwdg.de one of the main constituents [2]. The diverse characteristics of the ECM, such as stiffness and composition, have been recognized as being responsible for the variation of cellular behavior involving an individual's health $[3,4]$.

Basement membranes (BMs) are highly specialized extracellular matrices (sECMs) forming thin acellular layers that underlie cells and separate the cells from and connect them to their interstitial matrix [5]. The formation of BMs is a prerequisite for normal tissue development and function [6, 7]. In addition, individual components of BMs regulate different biological activities, such as the development, proliferation, differentiation, growth, and migration of cells, via cell surface receptors (mostly integrins) and non-integrin-receptors [8]. Furthermore, BMs control cellular functions by binding and modulating the local concentrations of growth factors and cytokines [4, 9]. BMs are able to regulate cell polarity $[10,11]$, cell adhesion, spreading, and migration via their effects on the cytoskeleton [12-14]. Adult tissues need a highly selective sECM to maintain their stem cell properties particularly in stem cells during development $[15,16]$ and it has been shown that BMs have been implicated in niche function [17].

BMs are made of diverse extracellular matrix molecules depending on the tissue in which they are localized. Due to the discovery of new components and isoforms, the complexity of BM composition has been considerably increased, providing an impressive number of tissue- and site-specific BMs [18]. The ability of BMs to adapt to changing cell biological requirements is dependent on how the components are deposited and arranged inside the matrix (for review, see [14, 19]). The deposition of BM components is also dependent on aging, as has been demonstrated using mouse retina and cartilage tissue [20, 21]. BM components can also be localized in the ECM, independent of the typical membrane-like structures seen 
in electron microscopy. Recently, it has been shown that $\mathrm{BM}$ components are found in the pericellular matrix of human and murine cartilage and osteoarthritis disease [21-23]. In the lymph nodes, BM components are deposited outside a BM structure [5]. Changes in the qualitative or quantitative composition, localization, or structure of BM proteins have been shown to be involved in the development of different disease states as discussed in detail below.

Herein, we want to briefly introduce the ubiquitous components of the BM including laminins, perlecan, collagen IV, nidogen-1, and nidogen-2 [5], with emphasis placed on their variable tissue distributions. We will further discuss the role of BM components and their uniqueness in different stem cell niches.

\section{Ubiquitous BM components at a glance}

Excellent detailed reviews regarding these unique matrix proteins and receptors, such as integrins, have just recently been published and the reader is directed to these reviews for comprehensive information [4, 14, 24-33]. An overview can be found in Table 1.

\section{Laminins}

Laminins are heterotrimeric glycoproteins, which are composed of three chains including one $\alpha$, one $\beta$, and one $\gamma$ chain. Five alpha, four $\beta$, and three $\gamma$ chains exist, and in vertebrates, these chains can assemble into at least 16 [25] different isoforms [14, 34]. These isoforms are differentially distributed during development and in adult tissues, thereby fulfilling specific functions as key regulators of tissue structure and cell behavior [35]. In general, laminin111 and laminin-511 are the main laminins required during embryonic development (Fig. 1a, b), whereas other laminins have been identified as being important for organ maturation and specific tissue functions [26]. For instance, laminin-211 and laminin-221 are mainly found in skeletal muscle [36, 37]. Laminin-221, -421 and -521 are localized to the neuromuscular junction and coordinate postsynaptic with presynaptic maturation [38]. Laminin-511 is the major laminin in ectodermal BM and in most epithelium including the skin, kidney, and lung to name a few. Laminin-332 plays a major role in skin function [39]. Furthermore, laminin-332 has been previously shown to be transiently expressed in embryonic cartilage [40]. Laminin111 has been observed in the chondrocytes of healthy human cartilage especially that which is localized to the superficial layer [41] where the mesenchymal progenitor cells are localized [42, 43]. In the vasculature, laminin-411, $-421,-511$ and -521 can be found. Although this laminin deposition appears to be significantly varied, the tissue distribution of laminins is mainly dependent on the expression of its alpha subunits, though the mechanisms are not yet fully understood [25]. However, it is well known that alpha subunits and their specific interaction with integrins or non-integrin receptors are essential for the self-assembly and polymerization of laminin networks. This network assembling is a prerequisite for basement membrane formation $[25,26]$. To name just a few lamininreceptor specificities, $\alpha$-dystroglycan presumably binds laminin $\alpha 1$ and $\alpha 2$ chains, whereas the Lutheran blood group glycoprotein binds only laminin $\alpha 5$ chains. Integrins such as $\alpha 3 \beta 1, \alpha 6 \beta 1$ and $\alpha 6 \beta 4$ can regulate the deposition of laminin-332 in keratinocytes [14] and interact with laminin $\alpha 5$ chains [26]. Further integrin receptors for laminins are known as the $\alpha 1 \beta 1, \alpha 2 \beta 2, \alpha 7 \beta 1$ (via laminin $\alpha 2$ ), $\alpha 9 \beta 1$, and $\alpha \mathrm{v} \beta 3$ (via laminin $\alpha 4$ ) receptors, as well as the non-integrin receptor syndecans [25].

It has been demonstrated by immunogold electronmicroscopy that laminin-111 is oriented differently inside the $\mathrm{BM}$ of the same tissue, for tissues such as the proximal and distal tubule (Fig. 1c, d) of the murine kidney [44]. Furthermore, laminin-211 and -221 that are located in Schwann cells are deposited in mesh-like structures for organizing the receptors and cytoskeletal elements [45], whereas a fibrillar network, for example, of laminin-311 in the lung seems ideal for the transmission of mechanosignals such as stretch [46]. The pattern and stabilization of laminins is further influenced by other BM components, such as nidogens or perlecan [14]. Moreover, the deposition pattern of laminin-332 has been shown to vary for nonmigratory and migratory keratinocytes in vitro. While nonmotile cells revealed a rosette-like pattern of laminin-332 in their matrix, motile cells assembled trails for migration [13]. Under physiological or pathological conditions (e.g., metastasis), fragments of laminins not able to polymerize into networks are deposited into the ECM, thereby stimulating cell migration as shown for laminin-332 [47-49].

According to the functions of laminins in BMs, it should be mentioned that the ability of laminin subunits to accumulate into heterotrimers and further assemble networks is absolutely required for the initial BM assembly [26]. In Drosophila, it has been shown that the complete absence of laminin leads to the complete absence of BMs resulting in a disorganized ECM and an abnormal accumulation of major BM components. Organ and tissue development is subsequently prevented in the gut, muscle and nervous system [50]. The important functions of laminin isoforms in tissues can further be demonstrated by analysis of knockout mice or of various mutations in mice, which also resemble human diseases. Most laminin subunit knockouts are lethal, such as laminin $\gamma 1$ [7], due to the lack of BM formation [25]. If the mice survive, they develop severe diseases, 
Table 1 Overview of BM components in specialized ECMs (mentioned in the text)

\begin{tabular}{|c|c|c|c|c|}
\hline $\mathrm{BM}$ isoform & $\begin{array}{l}\text { Interactive } \\
\text { receptors/ligands }\end{array}$ & Site of expression & $\begin{array}{l}\text { Phenotypes of } \\
\text { deficient mice }\end{array}$ & $\begin{array}{l}\text { Involvement in } \\
\text { human diseases }\end{array}$ \\
\hline Laminin-111 & $\begin{array}{l}\text { Lam } \alpha 1: \alpha- \\
\quad \text { dystroglycan }\end{array}$ & $\begin{array}{l}\text { Development, } \\
\text { ubiquitously in } \\
\text { BMs, adult } \\
\text { articular cartilage }\end{array}$ & Lam $\gamma 1$ : lethal & \\
\hline Laminin-211 & $\begin{array}{l}\text { Lam } \alpha 2: \alpha 7 \beta 1, \alpha- \\
\quad \text { dystroglycan }\end{array}$ & $\begin{array}{l}\text { Skeletal muscle, } \\
\text { schwann cells, } \\
\text { eye (limbal } \\
\text { compartment) }\end{array}$ & $\begin{array}{l}\text { Lam } \alpha 2 \text { : congenital muscular } \\
\text { dystrophy }\end{array}$ & $\begin{array}{l}\text { Congenital muscular } \\
\text { dystrophy }\end{array}$ \\
\hline Laminin-221 & & $\begin{array}{l}\text { Skeletal muscle, } \\
\text { schwann cells, } \\
\text { neuromuscular } \\
\text { junction }\end{array}$ & $\begin{array}{l}\text { Lam } \beta 2 \text { : defective, disorganized } \\
\text { neuromuscular junctions }\end{array}$ & Pierson syndrome \\
\hline Laminin-332 & $\begin{array}{c}\text { Lam } \alpha 3: \alpha 3 \beta 1, \\
\quad \alpha 6 \beta 1, \alpha 6 \beta 4\end{array}$ & $\begin{array}{l}\text { Skin, embryonic } \\
\text { cartilage }\end{array}$ & Severe skin blistering disease & $\begin{array}{l}\text { Epidermolysis } \\
\text { bullosa } \\
\text { Fragments: cancer/ } \\
\text { metastasis }\end{array}$ \\
\hline Laminin-411 & Lam $\alpha 4: \alpha \mathrm{v} \beta 3$ & Vasculature & $\begin{array}{l}\text { Lam } \alpha 4 \text { : hemorrhaging, } \\
\text { cardiomyopathy }\end{array}$ & $\begin{array}{l}\text { Inflammation } \\
\text { Lam } \alpha 4 \text { increased in } \\
\text { cancer/metastasis }\end{array}$ \\
\hline Laminin-421 & & $\begin{array}{l}\text { Vasculature, } \\
\text { neuromuscular } \\
\text { junction }\end{array}$ & & \\
\hline Laminin-511 & $\begin{array}{l}\text { Lam } \alpha 5 \text { : } \\
\text { Lutheran } \\
\text { Bloodgroup } \\
\text { glycoprotein, } \\
\text { B-CAM, } \alpha 3 \beta 1, \\
\alpha 6 \beta 1, \alpha 6, \beta 4\end{array}$ & $\begin{array}{l}\text { Development, } \\
\text { vasculature, } \\
\text { epithelium }\end{array}$ & $\begin{array}{l}\text { Lam } \alpha 5 \text { : impaired hair follicle, } \\
\text { teeth growth and development, } \\
\text { defective glomerulogenesis }\end{array}$ & $\begin{array}{l}\text { Lam } \alpha 5 \text { decreased in } \\
\text { cancer/metastasis }\end{array}$ \\
\hline Perlecan & $\begin{array}{l}\text { Interaction with } \\
\text { and support of } \\
\text { diverse growth } \\
\text { factors }\end{array}$ & $\begin{array}{l}\text { Ubiquitously in } \\
\text { BMs, articular } \\
\text { cartilage, growth } \\
\text { plate }\end{array}$ & $\begin{array}{l}\text { SJS: chondrodysplasia, myotonia, } \\
\text { short stature } \\
\text { DDSH: lethal, chondrodysplasia, } \\
\text { exencephaly, abnormal heart } \\
\text { development, absence of } \\
\text { acetylcholinesterase at } \\
\text { neuromuscular junction }\end{array}$ & $\begin{array}{l}\text { SJS, DDSH (lethal) } \\
\text { Osteoarthritis, } \\
\quad \text { cancer/metastasis }\end{array}$ \\
\hline Collagen IV-(112) & $\alpha 1 \beta 1, \alpha 2 \beta 1$ & $\begin{array}{l}\text { Development, } \\
\text { ubiquitously in } \\
\text { BMs }\end{array}$ & Lethal & $\begin{array}{l}\text { Collagen IV } \alpha 1 \text { : } \\
\text { HANAC } \\
\text { syndrome, } \\
\text { encephaloclastic } \\
\text { porencephaly, } \\
\text { recurrent } \\
\text { hemorrhagic } \\
\text { stroke }\end{array}$ \\
\hline Collagen IV-(345) & $\begin{array}{l}\alpha 3 \beta 1, \alpha 6 \beta 1 \\
\alpha 10 \beta 1, \alpha 11 \beta 1 \\
\alpha \mathrm{v} \beta 3, \mathrm{CD} 44 \\
\text { DDR-1 }\end{array}$ & $\begin{array}{l}\text { Kidney, inner ear } \\
\text { (cochlea), eye, } \\
\text { testis, lung }\end{array}$ & $\begin{array}{l}\text { Collagen IV } \alpha 3, \alpha 4 \text { or } \alpha 5 \rightarrow \text { Alport } \\
\text { syndrome: progressive renal } \\
\text { failure/fibrosis, disrupted } \\
\text { glomerular BM, deafness and }\end{array}$ & $\begin{array}{l}\text { Alport syndrome } \\
\text { Goodpasture } \\
\text { syndrome }\end{array}$ \\
\hline Collagen IV-(556) & & $\begin{array}{l}\text { Bowman's capsule } \\
\text { (kidney), skin, } \\
\text { esophagus, } \\
\text { smooth muscle } \\
\text { cells, synovia } \\
\text { (knee) }\end{array}$ & retinopathy, lethal & $\begin{array}{l}\text { Every collagen IV } \\
\text { isoforms as } \\
\text { fragments: } \\
\text { metastasis (?) }\end{array}$ \\
\hline
\end{tabular}


Table 1 continued

\begin{tabular}{|c|c|c|c|c|}
\hline $\mathrm{BM}$ isoform & $\begin{array}{l}\text { Interactive } \\
\text { receptors/ligands }\end{array}$ & Site of expression & $\begin{array}{l}\text { Phenotypes of } \\
\text { deficient mice }\end{array}$ & $\begin{array}{l}\text { Involvement in } \\
\text { human diseases }\end{array}$ \\
\hline Nidogen-1 & $\begin{array}{l}\alpha \mathrm{v} \beta 3, \alpha 3 \beta 1, \\
\text { Laminin } \gamma 1, \\
\text { collagen IV, } \\
\text { perlecan, } \\
\text { fibronectin, } \\
\text { collagen I, } \\
\text { collagen II }\end{array}$ & $\begin{array}{l}\text { Ubiquitously in } \\
\text { BMs, limb } \\
\text { development, rib } \\
\text { anlagen, adult } \\
\text { articular cartilage }\end{array}$ & $\begin{array}{l}\text { Single: neurological defects, } \\
\text { epilepsy, structural alterations in } \\
\text { brain capillaries and lens } \\
\text { capsule, impaired wound } \\
\text { healing }\end{array}$ & $\begin{array}{l}\text { Osteoarthritis, } \\
\text { metastasis (?) }\end{array}$ \\
\hline \multirow[t]{2}{*}{ Nidogen-2 } & \multirow{2}{*}{$\begin{array}{l}\text { Laminin, } \\
\text { collagen IV, } \\
\text { perlecan, } \\
\text { fibronectin, } \\
\text { collagen I, } \\
\text { collagen II }\end{array}$} & \multirow{2}{*}{$\begin{array}{l}\text { Like nidogen-1, but } \\
\text { more restricted in } \\
\text { muscle, } \\
\text { neuromuscular } \\
\text { junction and } \\
\text { cartilage }\end{array}$} & Single: no phenotype & Osteoarthritis \\
\hline & & & $\begin{array}{l}\text { Both nidogens: lethal, syndactyly, } \\
\text { lung and heart abnormalities, } \\
\text { microhemorrhaging of skin }\end{array}$ & $\begin{array}{r}\text { Ovarian cancer } \\
\text { (biomarker?) }\end{array}$ \\
\hline
\end{tabular}

Lam Laminin, SJS Schwartz-Jampel-syndrome, DDSH dyssegmental chondrodysplasia of the Silverman-Handmaker-Type, HANAC hereditary angiopathy with nephropathy, aneurysm and muscle cramps

Fig. 1 Laminin-111 is found in the very early mouse embryo, here shown at day 6, even before a proper BM has assembled (a) and in BM remnants of migrating mesodermal cells $(\mathbf{b})$ at day 7. $M$ Mesodermal cell, $N$ nucleus, $S$ mesodermal space, $E C$ ectodermal cell. (Taken from [200], with permission from the publisher). In adult murine kidney, the tail (formerly the E8 domain) of laminin-111 is orientated towards the lamina fibroreticularis in the basement membrane of the proximal tubule (c), while the molecule is randomly distributed in the distal tubule (d). $C$ Cell, $B M$ basement membrane. (Taken from [44], with permission from the publisher)

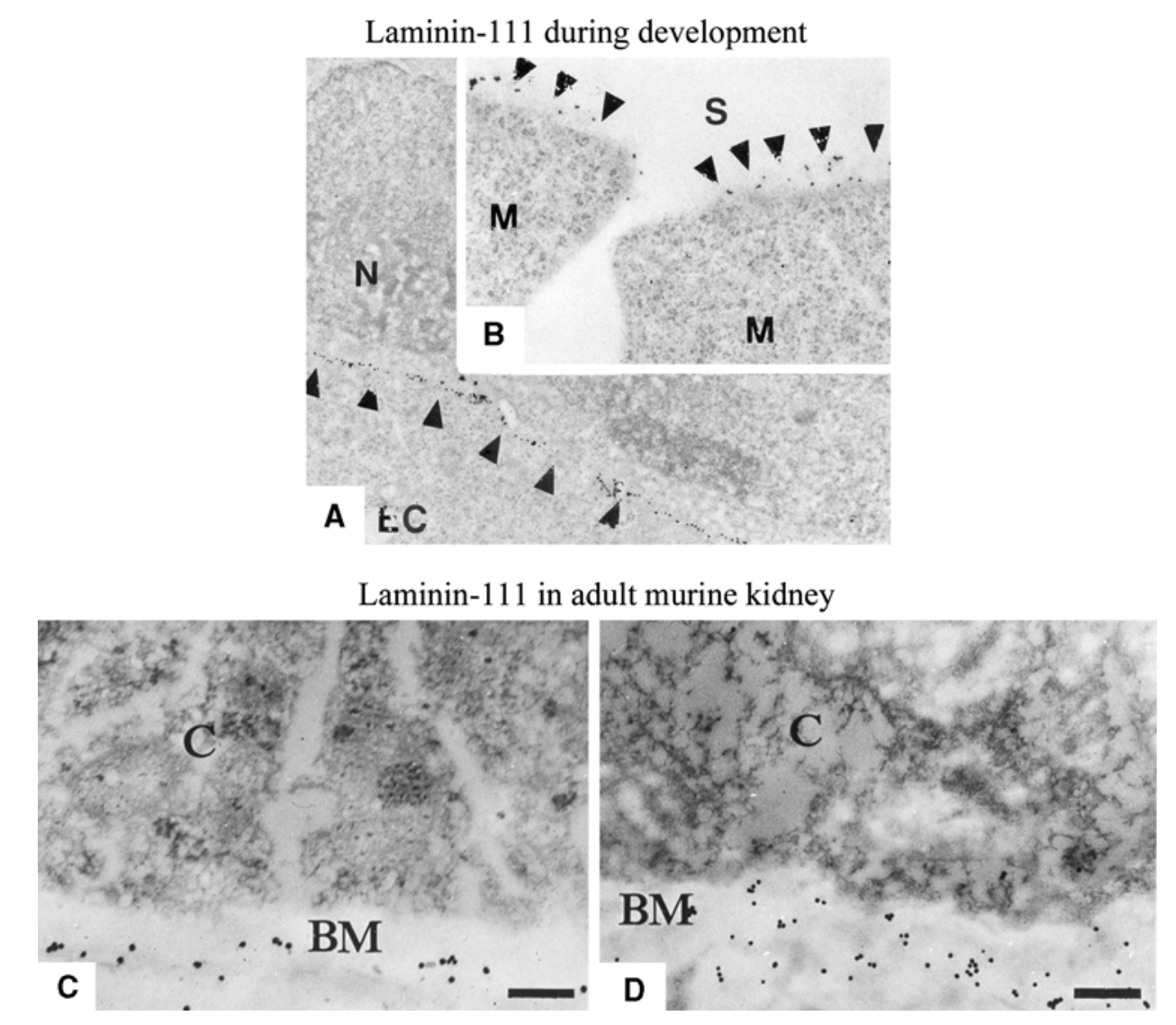

according to the subunits and their tissue distributions. Laminin $\alpha 2$ deficiency, known to affect humans, causes congenital muscular dystrophy [51], while laminin $\beta 2$ deficiency, known in humans as Pierson syndrome, results in disorganized and defective neuromuscular junctions [52, 53]. Laminin $\alpha 5$ deficiency causes impaired hair follicle, teeth growth and development issues [54] as well as defective glomerulogenesis [55]. Laminin-332 mutations are related to epidermolysis bullosa, a severe skin blistering disease [56, 57], while laminin $\alpha 4$ mutations cause hemorrhaging and cardiomyopathy [58]. Furthermore, laminins are known to be involved in cancer development and metastasis [48]. Additionally, laminins have been shown to play a role in the growth and/or differentiation of embryonic and adult stem/progenitor cells, which will be discussed in detail below. 
Fig. 2 Perlecan is found in the pericellular matrix next to a healthy chondrocyte (a) and increased amounts next to an elongated chondrocyte (b) from osteoarthritic tissue. (Taken from [23], with permission from the publisher)

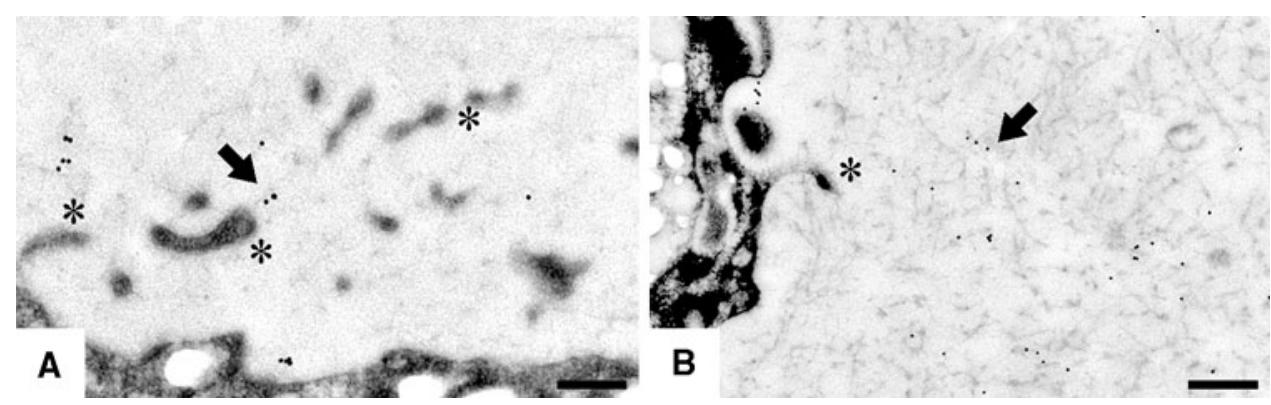

Perlecan

Perlecan is a proteoglycan composed of five domains, and like laminins, has the ability to self-assemble into oligomers [59]. Structurally, perlecan exhibits potential sites for glycosaminoglycan-(GAG)-chains proximal to its protein core like heparan sulfate (HS) and chondroitin sulfate (CS). Both the protein core and the GAG-chains are able to interact with diverse ECM molecules including all the main BM components, growth factors and receptors [28, 29], thereby initiating and controlling the migration, proliferation and differentiation of different cells by mediating cell signaling events. As typical for proteoglycans, perlecan mediates these functions by mainly controlling growth factor signaling and activation of fibroblast growth factors (FGFs), bone morphogenic proteins (BMPs), plateletderived growth factor (PDGF), vascular endothelial growth factors (VEGFs), transforming growth factors (TGF $\beta \mathrm{s}$ ), epithelial growth factor (EGF), hepatocyte growth factor (HGF), and insulin-like growth factor (IGF) [28, 59-62].

Perlecan is important in the developmental processes [63] that occur during angiogenesis [64], anti-angiogenesis [65], cardiovascular development [66], neurogenesis [67], and chondrogenesis [68]. Although there is only one perlecan, tissue-dependent structural differences have been reported [28, 68]. The GAG-chains can vary between different tissues enabling perlecan to fulfill tissue-specific functions, such as significant amounts of HS-chains that are important for endothelial cells and angiogenesis [28]. However, in articular cartilage, particularly high amounts of CS-chains are found. The GAGs of perlecan play crucial roles in the differentiation potential of cells [69]. Interestingly, these cartilage-specific perlecan CS-chains are also able to influence ECM by stimulating collagen fibril formation [70]. Furthermore, a fragment of perlecan, endorepellin (domain $\mathrm{V}$ of perlecan), has anti-angiogenic functions due to integrin $\alpha 2 \beta 1$ and is thought to be a potentially useful tool in future cancer therapy [71].

Mutations, resulting in reduced perlecan, resembles Schwartz-Jampel syndrome (SJS) in humans [72, 73]. Patients develop skeletal chondrodysplasia and myotonia and are characterized by short stature. Moreover, a total knockout of perlecan in humans and mice results in dyssegmental chondrodysplasia of the Silverman-Handmaker type (DDSH) and early lethality due to respiratory distress [74]. A severe chondrodysplasia, ex- or microencephaly, abnormalities in heart development and the absence of acetylcholinesterase at the neuromuscular junction have been observed [72, 74]. ECM and BM disruption appear to be major factors for these findings, as cartilage ECM and BM integrity has been found to be mainly interrupted in the cartilage, heart and brain tissue $[67,75]$. Furthermore, perlecan has been shown to increase in osteoarthritic cartilage (Fig. 2), possibly due to regeneration efforts [23].

\section{Collagen IV}

Collagen IV is made up of 6 different alpha chains that can assemble into 3 different heterotrimers, $\alpha 1 \alpha 1 \alpha 2$ (IV), $\alpha 3 \alpha 4 \alpha 5$ (IV), or $\alpha 5 \alpha 5 \alpha 6$ (IV) [27, 76]. These combined networks show a tissue-specific distribution (Fig. 3) and thereby define BM structure and function [77]. During development, collagen, which is an $\alpha 1 \alpha 1 \alpha 2$ (IV) network, is ubiquitously distributed in BMs. During the maturation process, this network gets partially replaced, for example, by collagen $\alpha 3 \alpha 4 \alpha 5$ (IV) in the glomeruli of the kidney, in the cochlea, eyes, testis and lung, and by collagen $\alpha 5 \alpha 5 \alpha 6$ (IV) in the bowman's capsule of the kidney, the skin, esophagus and smooth muscle cells [78] as well as in the human synovial lining of the knee joint [79].

The mechanical stability, as opposed to the assembly of BMs, is largely dependent on its collagen IV scaffold [77, 80]. Many different cells have been shown to bind to collagen IV including platelets, hepatocytes, keratinocytes, and endothelial, mesangial, and pancreatic cells, as well as diverse tumor cells [27]. These interactions are mediated by integrins and non-integrin receptors, which show a collagen IV chain-specific binding [27]. Integrins such as $\alpha 1 \beta 1, \alpha 2 \beta 1, \alpha 3 \beta 1, \alpha 6 \beta 1, \alpha 10 \beta 1, \alpha 11 \beta 1, \alpha \mathrm{v} \beta 3$, and $\alpha \mathrm{v} \beta 5$ have been described [27], while non-integrin receptors such as CD44 [27] and discoidin domain receptor-1 (DDR1) have been reported [81]. DDR-1-collagen IV interactions have been demonstrated to be important for the structural integrity and filtration function of the BMs in the kidney [82]. 


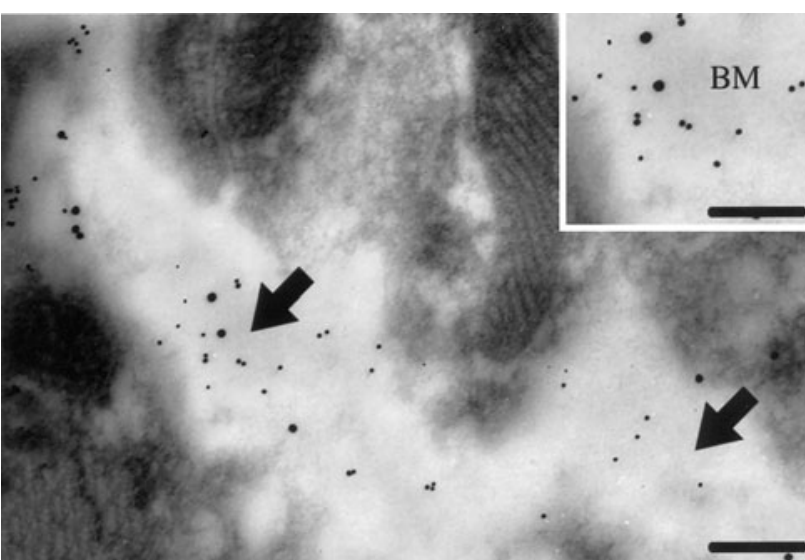

Fig. 3 The interconnected networks of laminin-111 (large gold particles) and collagen IV (small gold particles) is here shown in a basement membrane of the kidney. The inset shows a higher magnification. $B M$ Basement membrane. (Taken from [201], with permission from the publisher)

It has been demonstrated that the proteolytic degradation or denaturation of collagen IV results in novel binding sites [83] that could further effect and alter integrin specificity and the biological functions of collagen IV [27]. This proteolytic cleavage, for example, was shown to support angiogenesis [84]. Furthermore, a proteolytic fragment of $\alpha 3$ (IV), namely tumstatin, has anti-angiogenic activity and is discussed as a potential candidate for cancer therapy [85].

Notably, the $\alpha 1$ (IV) and $\alpha 2$ (IV) mutations are typically embryonic lethals [77]. However, in humans, mutations in the $\alpha 1$ (IV) may not be lethal and can exhibit a phenotypic heterogeneity. A cerebrovascular disease, known as HANAC syndrome (hereditary angiopathy with nephropathy, aneurysm and muscle cramps), has been described [86]. Furthermore, neurological diseases such as encephaloclastic porencephaly or vascular diseases such as recurrent hemorrhagic stroke are associated with mutations in collagen $\alpha 1$ (IV) [86]. Autoantibodies against the $\alpha 3$ (IV) chain leads to Goodpasture syndrome, a rapidly progressive glomerulonephritis associated with lung hemorrhage [87]. In addition, $\alpha 3$ (IV), $\alpha 4$ (IV) or $\alpha 5$ (IV) mutations cause Alport syndrome, which leads to renal failure, deafness and retinopathy in patients $[27,88,89]$. Stem cell therapies that could benefit Alport syndrome have just recently been described [90].

\section{Nidogens}

Nidogen-1/entactin-1 [91] and nidogen-2/entactin-2 [92] are BM glycoproteins. Structurally, they appear highly similar. Both nidogens consist of three globular domains that are separated by a link-like and a rod-like region
$[92,93]$. In addition, both are known to act with a wide range of BM proteins [30, 91, 92]. Nidogens are mainly expressed by mesenchymal cells and are deposited into the epithelial and endothelial BMs during development [94]. In skin tissue, fibroblasts have been described to be the source of nidogens [92, 95]. Nidogen-1 and nidogen- 2 have been observed in the mesenchyme of different murine tissues during limb development [96] and have been shown to exist in the rib anlagen [97]. Furthermore, both nidogens have been described in murine and human adult articular cartilage [21, 22].

Due to their similar structure and affinity to comparable ECM proteins, nidogens are thought to have similar functions such that they are capable of compensating for each other [97]. Indeed, in nidogen-1 or nidogen-2 knockout mice, BM formation is not interrupted [98]. Furthermore, a compensatory process has been shown for nidogen-2 in nidogen-1 knockout mice (Fig. 4), especially in muscle and heart tissue [99]. Nidogen double-knockouts are smaller than their wild-type littermates [100], exhibit syndactyly, and some of these animals have more severe defects of the skeleton, such as hypoplasia [101]. A double knockout leads to perinatal death as a consequence of lung and heart anomalies and BM defects [100, 102]. Also, the capillary BMs were disrupted with an almost complete loss of laminin-411 and reduction of collagen IV and perlecan, thereby causing microhemorrhages of the skin. However, some BMs still develop without abnormalities, such as the dermal-epidermal junction [103].

Nidogens are able to interact with different receptors and nidogen- 2 has an even more restricted tissue distribution (e.g., in muscle tissue) at the neuromuscular junction [104, 105] or in cartilage tissue (Fig. 5) [22]. While nidogen- 1 integrins such as $\alpha \mathrm{v} \beta 3$ and $\alpha 3 \beta 1$ have been described [106, 107], interactions with these integrins could not be observed for nidogen-2 [22, 92]. Nidogen-1 knockout mice developed neurological defects, showed altered anionic charges in the glomerular BM, were observed to have structural alterations in the BMs of brain capillaries and the lens capsule and were characterized with impaired wound healing [108-111]. These finding indicate diverse functions of nidogens.

Due to their strong affinity to laminin and collagen IV, nidogens are considered to be link-proteins in some BMs [30]. In particular, the laminin $\gamma 1$-nidogen- 1 complex has been shown to be important during organ development [94, 112, 113]. Nidogens are highly sensitive to proteolytic cleavage; however, laminin $\gamma 1$-binding can decrease this strong susceptibility to proteolysis as shown for nidogen-1 [113]. Moreover, the same protective effect has been reciprocally demonstrated [94], therefore the removal of nidogens might initialize BM disintegration. Furthermore, while they could be ideally suited for maintenance, they 

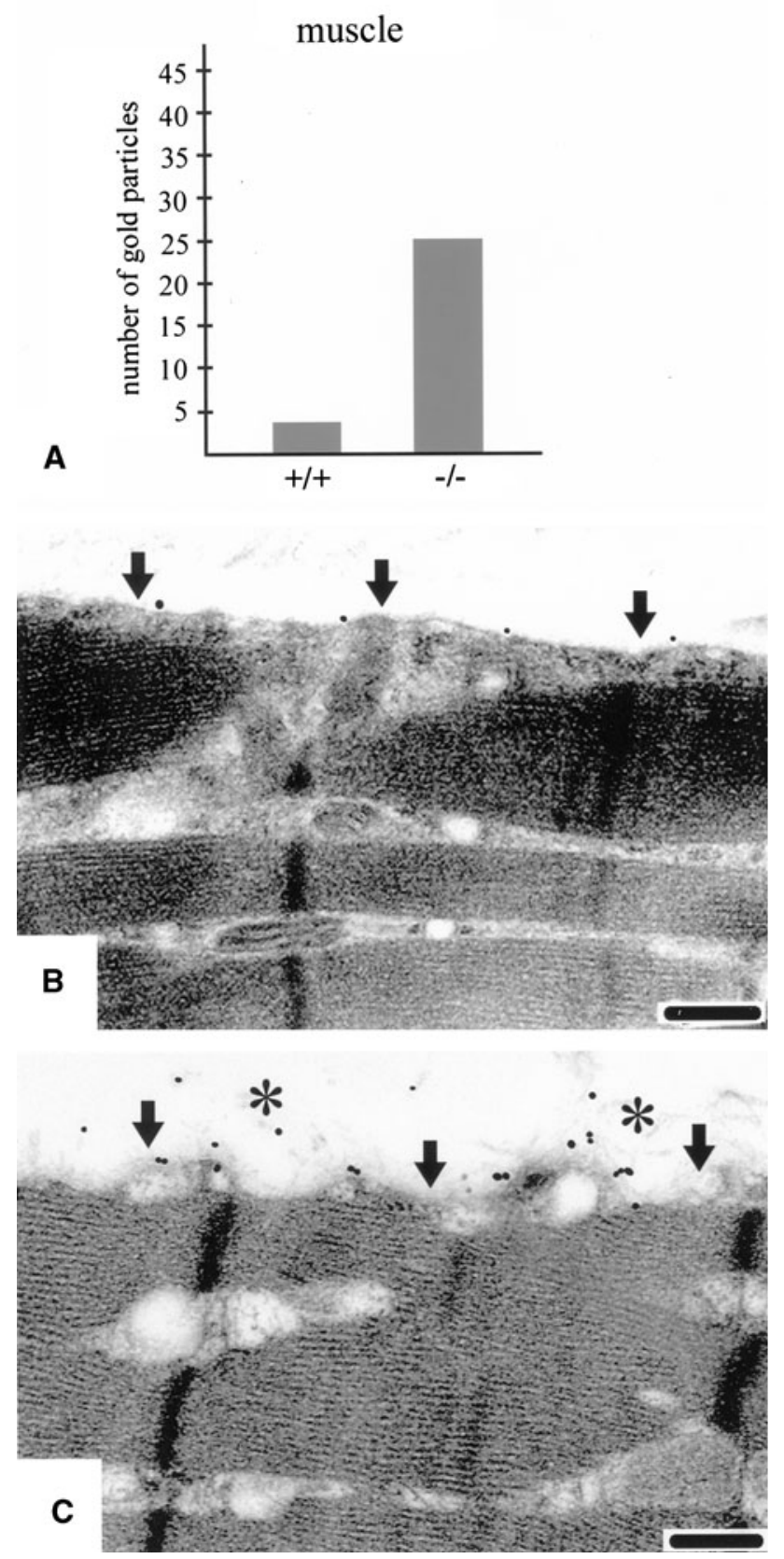

Fig. 4 More nidogen-2 is found in the BM of skeletal muscle in nidogen-1 knockout mice compared to control mice (a), sparse labeling of muscle BM of a control mouse (b), and a higher amount seen in a nidogen-1 knockout mouse (c). (Taken from [99], with permission from the publisher)

also may facilitate the fast remodeling of different matrices and might be early targets in tissue destruction pathways, such as metastasis [31]. Just recently, nidogen-2 has been observed to be strongly upregulated in the serum of patients with ovarian carcinoma and has been proposed as an additional cancer biomarker [114].

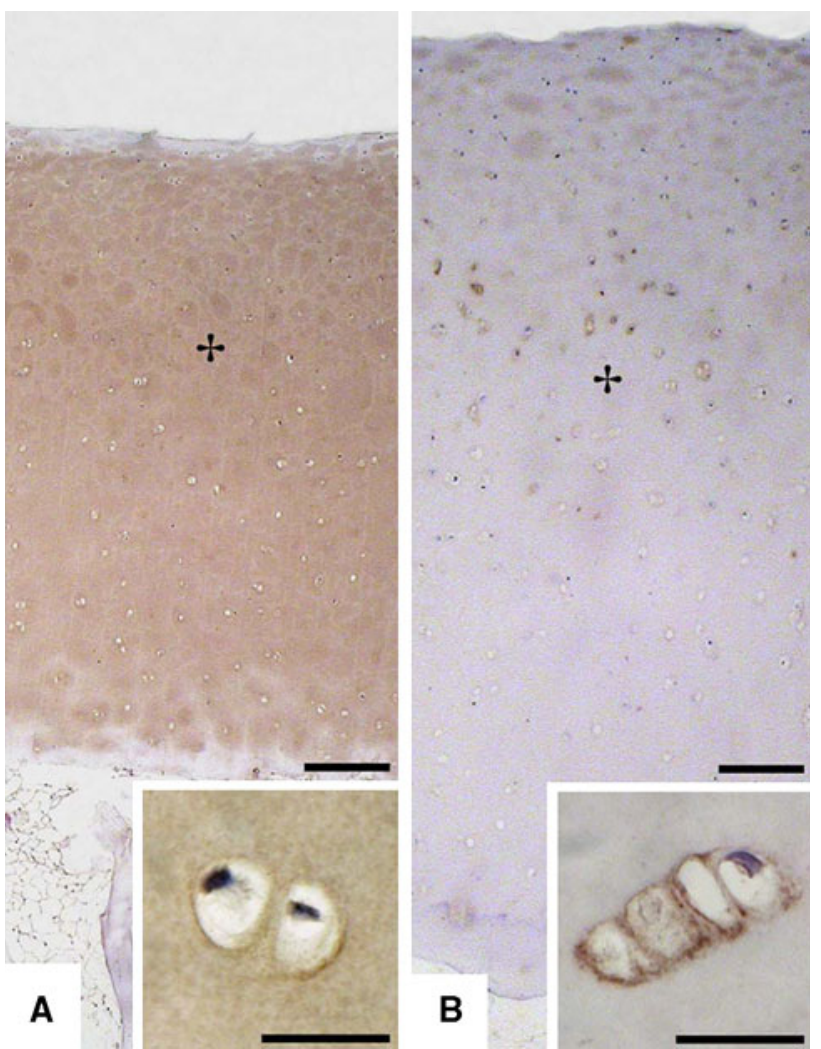

Fig. 5 Nidogen-2 (b) exhibits a more restricted tissue distribution in human articular cartilage than nidogen-1 (a). (Taken from [22], with permission from the publisher)

\section{A stem cell's niche is its specialized ECM}

Stem cells are important during development, regeneration and cancer development [115]. Embryonic stem cells (ESCs) are undifferentiated cells with the ability to develop into different tissues, whereas adult stem cells are thought to reside in specific tissues, with the possibility to regenerate the tissue if needed. Stem cells are embedded in a highly tissue-specific environment, which consists of an ECM with additional surrounding cells, such as organspecific mesenchymal cells [15]. A stem cell niche is defined as a microenvironment that regulates the maintenance, self-renewal, activation, proliferation and long-term regenerative capacity of stem cells via external signals. The niche is, therefore, a key prerequisite for proper stem cell function and fate determination [15, 116, 117]. A single sECM, along with integrins, growth factors and diverse proteases are interconnected in complex pathways in stem cell niches. Stem cell niches are thought to be anatomically localized in protected sites of tissues [118]. Defining the composition of stem cell niches would help to understand the regulation of stem cells and to exploit their therapeutic potential [9]. Furthermore, knowledge about niches in different organs can help to elucidate the emergence of 
diseases including diabetes, neurodegenerative diseases, cancer development and metastasis [60].

BMs are capable of governing cell fate by inducing signaling cascades, as well as stabilizing cellular structures. Thus, its components could potentially be used in stem cell and gene therapy approaches [119]. Over the last few years, there has been significant progress made in characterizing different stem cell compartments, such as the hematopoietic, epidermal, intestinal or neural stem cell niches [120-122]. Most niches contain a BM, to which stem cells attach [17]. The BMs are believed to have important functions for the structural integrity of stem cells [123]. They are also important for facilitating the polarization of cells, which is a prerequisite for proper symmetric and asymmetric cell division [61, 118, 124]. It has been suggested that, in contact with a BM, cells maintain their stemness, whereas cells that have detached from the BM undergo terminal differentiation [9].

Embryonic stem cells and their BM components

Human embryonic stem cells (hESCs) are seen by some as a potential source for therapeutic approaches, due to their indefinite proliferation in culture and ability to differentiate into various cell types [125]. Embryonic stem cells are colony-forming adherent and undifferentiated cells. Their adhesion mechanisms are important for their survival and differentiation and are thought to include a special ECM. Recently, it has been found that laminin-511 and nidogen-1 are expressed by human embryonic stem cells [126]. In addition, Lutheran-glycoprotein and its truncated form, basal cell adhesion molecule (B-CAM), which is a laminin511-receptor, has been reported. Furthermore, adhesion of hESCs was driven by $\alpha 3 \beta 1$ via laminin-511. Moreover, hESCs have been found to be positive for laminin-111 [127]. In vitro, single ESCs were able to reassemble into embryoid bodies with the aid of a laminin-nidogen-complex via $\alpha 6 \beta 1$ integrin, subsequently differentiating into endodermal, ectodermal and mesodermal derivates, as well as hematoendothelial progenitors [126]. Mimicking stem cell niches as a fibrous scaffold with a BM texture has been shown to increase the expansion of hematopoietic and ESCs [128]. Proper BM formation seems to be involved in the maintenance of the differentiation status of BM-coupled cells such as in the myotome or the central nervous system [129, 130]. During development, BMs seem to have an inhibitory effect on the progression of cell differentiation [131]. Notably, other reports have found that hESCs retained their undifferentiated state if cultured on Matrigel $^{\circledR} \quad$ (includes mainly laminin-111), whereas hESCs underwent differentiation on substrates like fibronectin [132, 133].
BMs are important contributors during epithelialmesenchymal-transition (EMT)

During development, undifferentiated cells in contact with BMs become polarized and as a consequence form the ectoderm [131]. Furthermore, using ESC-derived embryoid bodies (EBs), evidence demonstrates that unpolarized cells that fail to contact the BM undergo apoptosis, which leads to cavitations that create the proamniotic cavity [131, 134, 135].

Gastrulation, which leads to the formation of the mesoderm and endoderm, involves an event known as the epithelial-mesenchymal-transition (EMT). During this process, cells of the primitive ectoderm become activated by exogenous stimuli, followed by a loss of contact with the neighboring cells and the underlying BM that promotes the migration of cells into the space between the ectoderm and the extraembryonic endoderm [131]. Fujiwara et al. [131] proposed that the BM not only promotes the epithelialization of primitive ectoderm cells [135] but also promotes mesodermal differentiation by influencing the expression of genes important for mesodermal differentiation. In laminin $\gamma 1$ knockout mice, BM deposition did not occur, resulting in the failure of ectoderm formation [131]. Furthermore, the destabilization of collagen IV induced EMT in renal cell cultures [136].

For proper EMT, the cytoskeleton has to become reorganized to allow the cell to migrate. Therefore, cell-to-cell contacts have to be reduced, while cell-to-ECM interactions have to be increased. [137]. In the presence of a BM, the actin cytoskeleton accumulated at the apicolateral region of the polarized cells, whereas in its absence, actin was distributed evenly throughout the unpolarized cells. Therefore, BMs prevent EMT initiation by influencing the dynamics of the actin cytoskeleton and the assembly and disassembly of junctional complexes [131]. During EMT, laminin-332 gets downregulated, indicating a mechanism that is important for proper cell invasion. Furthermore, it has been shown that proteolytic fragments of the laminin $\gamma 2$ chain liberated by MT1-MMP or MMP2 can trigger cell migration, therefore one could speculate that these fragments are generated during EMT, thus promoting cell migration [138].

BMs and EMT: a link to metastasis

Finding candidate marker genes for EMT would also have implications in cancer diagnosis, prognosis, treatment [138], and metastasis [139, 140]. EMT-genes such as Snail2 and Twist2 are also upregulated during cancer progression [131, 141, 142]. Changes in protein expression that are indicative of EMT include the upregulation of vimentin and a reduction in the expression of E-cadherin 
[9, 138]. Signaling pathways important for EMT induction include Wnt, TGF $\beta$, Hedgehog, Notch, and NFkB. Notably, some external stimuli that affect EMT induction include collagen, fibronectin, EGF, and HGF [138]. Cells undergoing EMT show a reduced expression of BM components such as laminin-332, nidogens and collagen IV $\alpha 1$ and $\alpha 2$ chains in addition to increased expression of proteases, such as MMPs. In addition, these cells demonstrate elevated secretion of ECM molecules important for the proliferation and migration of compounds such as collagen I and fibronectin [138, 143, 144]. Metastatic cells indeed showed significantly decreased to no expression of diverse laminin subunits, collagen IV and $\alpha$-dystroglycan compared to their non-metastatic counterparts [145-147]. In addition, during EMT, the downregulation of laminin $\alpha 5$ and the upregulation of laminin $\alpha 4$ have been observed, suggesting that tumor cells utilize laminin-411 due to their invasive behavior [148]. Furthermore, laminins and collagen IV are localized throughout the ECM of some cancer tissues [149, 150], indicating fragments of these proteins that are not able to self-assemble into BM structures. Laminin-332 fragments can improve cancer cell migration and, for this reason, it has been discussed as a potential target for cancer therapy $[151,152]$.

Depending on the stimulus, different MMPs are activated, such as cells activated by Ras that can upregulate MMP1. On the other hand, the activation of cells via HGF or Snail has been shown to activate MAPK signals, increasing the expression of MMP9 and MMP13 [138]. Furthermore, cell motility can be influenced by different integrin dependent pathways, including the Ras-Raf and MAPKinase or Rho- and Rac-controlled pathways [153, 154].

Adult stem cell niches: in vivo and in vitro

There is evidence that in different sites of the limbal compartment of the eye, various forms of typical BM components were localized, indicating that a different composition of ECM can regulate the phenotypic changes of the limbal cells and thereby regulate cell differentiation and migration via diverse cell-ECM-interactions [9]. The limbal stem cell compartment contains mostly collagen type IV $\alpha 1$ and $\alpha 2$, whereas collagen IV $\alpha 5$ and $\alpha 6$ chains were localized throughout the limbal and corneal BMs. Laminin-211 and -213 were most prominent and were shown to be specific for limbal BMs. While both nidogens and perlecan did not show any regional differences, laminin $\gamma 3$ showed a specific immunoreactivity in the limbal stem cell compartment.

The stem cell niche in skin has been recently reviewed [61]. The BM itself provides proliferative stimuli through the use of laminin-332 that stimulates anchorage, signaling and migration via $\alpha 6 \beta 1$ integrins at hemidesmosomes and $\alpha 3 \beta 1$ at focal adhesions [155, 156]. Laminin-332 supports cell adhesion and migration more efficiently than other laminins, which is mainly mediated by integrins $\alpha 3 \beta 1$, $\alpha 6 \beta 1$ and $\alpha 6 \beta 4$ [157]. It is important in skin and other epithelial tissues and it plays important roles in the stabilization of the epidermal-dermal-junction and in wound healing [157]. More specifically, it has been shown that the proliferation potential of such cells can be enhanced via exposure to $\beta 1$-integrins [156], which induces focal adhesion tyrosine kinase and Src tyrosine kinase, thereby stimulating the Ras-MAPK pathway and inducing epidermal migration. Balancing these pathways is known to be important for homeostasis and cancer development [158]. Notch signaling is one of the key mediators for the differentiation or the repression of basal cells via the regulation of integrin levels [61]. Muffler et al. [117] demonstrated that an increase in MMPs (MMP1 by basal keratinocytes, MMP2 by dermal fibroblasts) led to the degradation of collagen IV, laminin-332 and -511, nidogen and integrins $\alpha 6$ and $\beta 1$, thereby altering the long-term differentiation potential of the epidermis, which is thought to be due to stem cell niche destruction. It has been further proposed that integrin-nidogen-laminin-332 complexes could be promising components for the regulation of the stem cell niche and epidermal maintenance [117]. In vitro, collagen IV can be used to enrich proliferative human skin keratinocytes, with high levels of integrin $\alpha 6$ and $\beta 1$ subunits [159]. The $\alpha 6$ integrin subunit has been used for the isolation of human epidermal stem cells [160].

In the muscle stem cell niche $[62,161]$, it is suggested that the BM components regulate satellite cell behavior, as these cells lose their proliferative capacity in vitro, probably due to the loss of the BM components of its niche [162-164]. Several ECM molecules, including BM components, affect myoblast differentiation and proliferation $[165,166]$. The influence of BMs on satellite cells has been previously reviewed in detail [62]. Laminins in skeletal muscle interact with cell surface receptors to initiate BM formation [167]. Furthermore, a muscle-specific isoform of laminin-211 [6] has been characterized in the stem cell compartment that connects cells via integrin $\alpha 7 \beta 1$ and dystroglycan. Integrin $\alpha 7 \beta 1$ is also upregulated during the regeneration of muscle tissue. Integrin $\alpha 3$ plays a role in satellite cell migration and differentiation. Furthermore, the integrin $\beta 1$ in muscle tissue is important in myoblast attachment in vitro [161, 168]. Laminins have been shown to give rise to additional yet smaller myotubes, whereas collagen type IV or Matrigel ${ }^{\circledR}$ resulted in thicker yet fewer myotubes. In addition, the stiffness of the surrounding ECM influences the proliferation rate of myoblasts, resulting in higher stiffness associated with increased proliferation [169]. Yao et al. [170] have described a 
positive effect on myoblast migration through laminins via $\alpha 7 \beta 1$ integrins.

The stem cell niche of cardiac tissue in vivo has not yet been described in detail; however, it is known that fetal heart tissue and adult cardiomyocytes secrete collagen IV and fibronectin [171]. It has been hypothesized that cardiac stem cells are quiescent cells, surrounded by a BM, and if activated give rise to cells of the transient amplifying pool that are responsible for tissue repair [172]. Laminins in particular are known to play an essential role in cardiac tissue development, as elucidated by laminin $\alpha 2$ and $\alpha 4$ mutations [173]. Furthermore, laminin $\alpha 4$ mutations were shown to also result in endothelial and cardiac cell alterations [58]. Interestingly, in heart tissue, BMs are primarily important for the control of ECM assembly and deposition, thereby indirectly influencing cell behavior. Malan et al. [174] have recently shown that a lack of laminin $\gamma 1$ and a corresponding lack of BMs are not essential for the development and differentiation of hESC into cardiomyocytes. However, they detected a clearly stronger deposition of several ECM proteins, e.g., collagen I, VI and fibronectin, which resulted in an altered spacing between the cells and indirectly caused a defective intercellular coupling via gap junctions resulting in altered propagation of electrical signals. Furthermore, increased amounts of the pacemaker-like cells were found, suggesting a compensatory mechanism to overcome the increased ECM depositions and the alterations in the propagations of electrical signals. These results could explain the pathophysiological development of cardiomyopathies where the deposition of ECM is one of the main causes for life-threatening arrhythmias [174, 175]. Moreover, collagen IV plays an important role in cardiac tissue and shows an increased deposition in the ECM after myocardial infarction (for review, see [176]). It has been proposed that ECM deposition in heart tissue could be repressed, either by changing the integrin pattern to a more laminin-binding pattern and less fibronectinbinding integrins $(\alpha 5 \beta 1, \alpha v \beta 3)$, which could accelerate maturation and reduce ECM secretion, or by co-injections of hESCs with extracellular matrix molecules [125].

A special kind of niche is the vascular niche, which is important for cellular and developmental processes, for differentiation and proliferation of the stem and progenitor cells, as well as for the development of cancer metastasis. The influence of the vascular niche in diverse diseases has been reviewed previously [60, 177]. Despite exhibiting highly variable features in different tissues, Nikolova et al. [60] suggested that a common feature of all the vascular niches is to provide a BM to cells that are unable to form their own. Furthermore, these cells are dependent on their vascular niche to retain a high degree of plasticity [60].
Cells that are included in this niche are the endothelial cells and the smooth muscle cells in the macrovasculature or the pericytes of the microvasculature. In vitro, endothelial cells have been shown to be supportive in the differentiation of pancreatic cells [178], in the stimulation of the neurogenesis of neural stem cells [179], and in supporting the proliferation of myoblasts [180]. Co-transplantations of hESC-cardiomyocytes with hESC-endothelial cells could improve the formation of functional capillaries and the secondarily blood supply [125]. Moreover, recent data present in vitro and in vivo evidence for the important role of pericytes-endothelial interactions to stimulate BM formation and thereby stabilize vascular tube formation [181]. Collagen IV promotes the differentiation potential of ESCs to endothelial cells [182]. Due to their stem cell characteristics and their ability to produce BM components, pericytes are thought to be important for the function of the blood-brain barrier [183, 184]. Furthermore, pericytes enhance the low-tissue regeneration and proliferation capacity of epithelial cells by influencing the ECM microenvironment. Pericytes are a source of laminin $\alpha 3$ and $\alpha 5$, collagen IV $\alpha 1$ and $\alpha 2$ chains, integrin $\alpha 7$, and integrin $\alpha 1$ in human skin [184]. In organotypic cocultures, it has been found that they enhanced the deposition of laminin$511 / 521$ in the dermal-epidermal junction. These observations could be used for the ex vivo expansion of epidermal progenitors to treat skin defects [184]. In muscle tissue, a loss of capillaries leads to a loss of satellite cells, which is thought to result from an interaction of endothelial cells with satellite cells [180]. Furthermore, pericytes are able to differentiate into mesenchymal lineage cells [185]. Therefore, pericytes could also be a possible stem cell source in muscle tissue that would be able to differentiate into myoblasts. Changes in the BM composition and/or its destruction in vascular tissues could be important in different diseases, including multiple sclerosis or for diseases of the pancreas in the context of islet cell transplantation or autoimmune insulitis [123].

Improvement of culture conditions for adult stem cells

It has been proposed that stem cells require an authentic equivalent of their in vivo environment, rather than an artificial surrogate, such as collagen type I [117]. Muffler et al. [117] demonstrated a high regenerative capacity of human epidermal stem cells in scaffold organotypic cultures (OTCs) rather than in OTCs made up of collagen type I. The imitation of different tissue-specific ECMs can promote cell differentiation and proliferation in vitro [186], as has been shown, for example, by de-cellularized matrices of tissues, which were sufficient for the differentiation of stem cells into the cells and structures indicative of the respective tissue [187]. 
Fig. 6 Tissue from late stages of osteoarthritis exhibits brakes in the tidemark (a) through these mesenchymal cells and blood vessels enter the cartilage tissue (b), perhaps bring in stem cells from the mesenchyme underneath $(\mathbf{c})$. The progenitor cells are positive for STRO-1 (d) and CD29 (e), two so-called stem cell marker. (Taken from [199], with permission from the publisher)

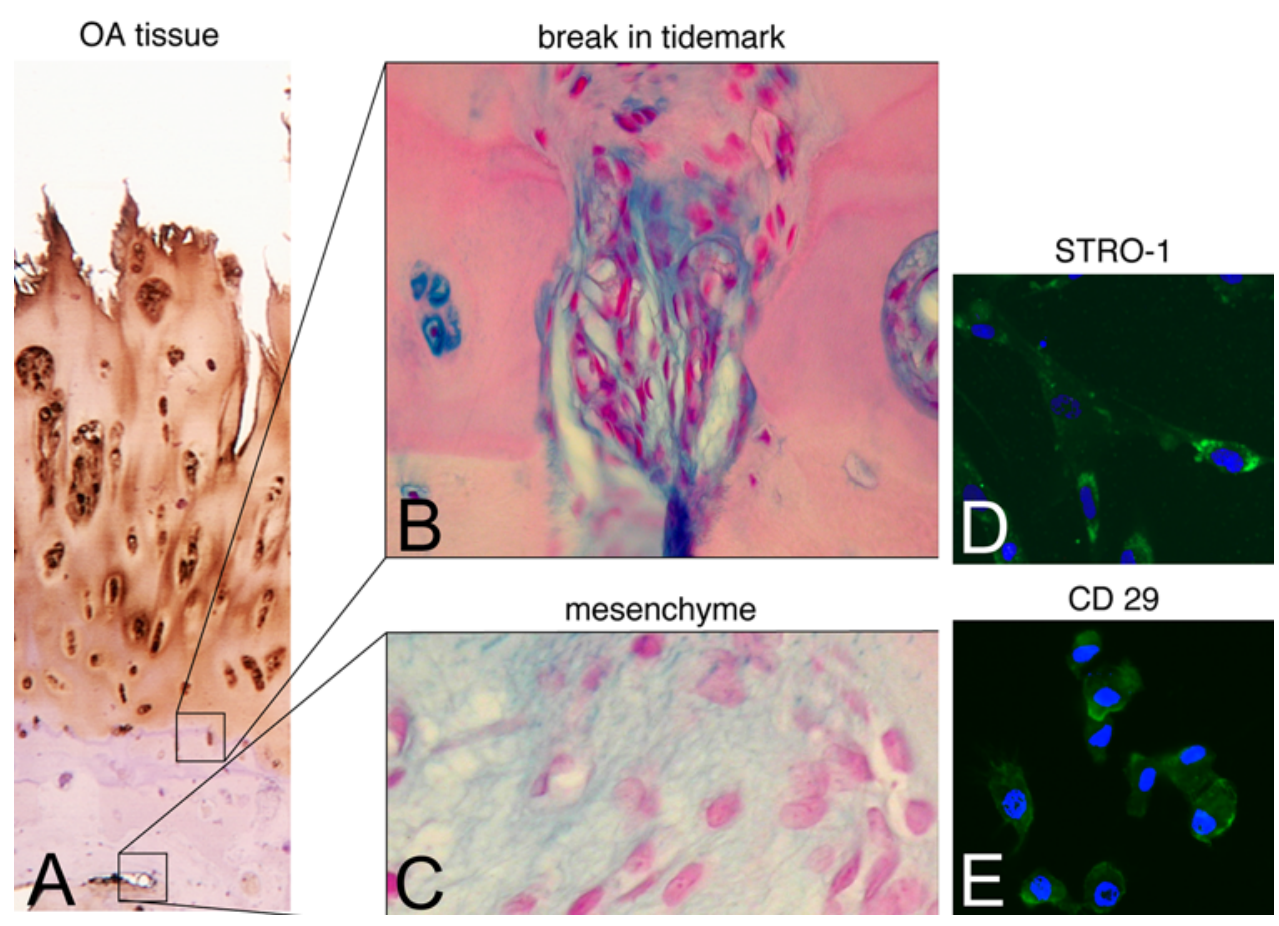

Adult mesenchymal stem cells and tissue engineering?

Mesenchymal stem cells (MSCs) could be a good starting point for tissue engineering approaches, as they have been shown to be multipotent cells with self-renewal abilities and a potential to differentiate into a variety of cell types $[188,189]$. MSCs are proposed to be directed to the sites of injury [190], suggesting them as a starting point to initiate regeneration [191, 192]. The observation that systemically delivered MSCs can integrate into a perivascular/intramural location has been shown by Toma et al. [192], indicating that perivascular tissues could function as a reservoir of tissue-specific regenerative cells [192]. It has been proposed that pericytes are a type of MSC and vice versa, due to their similarities $[184,186]$. Potapova et al. [193] found that endothelial cell migration, invasion through BMs, proliferation and survival can be supported by MSCs. Furthermore, MSCs can be differentiated into vascular cell types [186], whereas pericytes are able to be differentiated into mesenchymal lineages such as chondrocytes, adipocytes and osteocytes [184].

\section{Effect of BM components on adult MSCs}

The imitation of bone marrow cell-derived ECM (including laminin, perlecan, fibronectin, collagen I) in vitro has resulted in a complete bone-like structure in vivo that contained hematopoietic marrow with adipocytes and stromal cells that supported hematopoiesis and osteoclastogenesis [194], suggesting that marrow-derived ECM provides important micro-environmental cues in vivo and preserves the stem cell properties of MSCs [194]. ESCs could be differentiated into smooth muscle cells (SMCs) via collagen IV [195], whereas bone marrow-derived MSCs significantly increased their proliferation rate [188, 196]. Collagen IV positively influenced the proliferation of human bone marrow-derived MSCs, whereas laminin-111coating enhanced the smooth muscle cell differentiation marker expression [188].

It has been indicated that laminin-332 plays a suppressive role in chondrogenic differentiation of mouse embryonal carcinoma-derived chondroprogenitor cell lines [157]. Additionally rat periosteum, as well as human MSCs, express laminin-332, which induces osteogenic differentiation via an ERK signaling pathway [157, 197] suggesting a possible role for laminin-332 during bone development [157]. Laminin-332 has growth-stimulating activity depending on the type of target cell [49]. The soluble form of laminin-332 stimulated growth of MSCs via $\alpha 6 \beta 1$ integrin, thereby inhibiting chondrogenic differentiation. Moreover, laminin-332 promoted attachment and spreading of MSCs in vitro [157]. The suppression to one cell lineage by laminin-332 may favor the commitment of MSCs to other cell lineages (adipocytes or myoblasts) as proposed by Hashimoto et al. [157].

Perlecan might improve the bioavailability of diverse growth factors in vitro to increase the proliferation and differentiation potential of MSCs. BMPs and TGF $\beta$ s are widely used in vitro to improve chondrogenesis [198] and for mesenchymal stem cell-like cells from human osteoarthritis (Fig. 6) as described recently [199]. 


\section{Conclusion}

Understanding of the structure and components of the human BMs in different tissues would have important implications for the development of more physiologically relevant conditions for the optimized cell growth and differentiation of cell lines in vitro, due to the importance of environment in maintaining specific cell properties in vitro.

Mimicking a tissue-specific stem cell niche will help facilitate stem cell self-renewal and create a controlled differentiation ex vivo environment. The identification of specific niche parameters of diverse tissue types in vivo will not only help to understand stem and progenitor cell regulation but will also further improve their enrichment and in vitro expansion for cell biologically relevant therapeutic strategies. It has been shown that BM components could be used to create an in vivo-situation for maintaining stem cell properties and that they are a useful tool in tissue engineering techniques. The receptor expression pattern of integrins, for example, and their signaling pathways in $\mathrm{hESC}$ and adult stem cells requires further investigation to produce a better understanding of how stem cells modulate their specific environment to create optimal niche conditions. Further work is needed to understand the complex microenvironments created mainly by BM components of different tissues, their stem cells and progenitors during homeostasis, diseases and repair.

Acknowledgment This work is dedicated to the late Dr. Rupert Timpl, who initiated our interest in matrix research. We would like to thank the members of our group for helpful discussions. We would like to apologize to those of our colleagues whose work we were unable to cite in this review due to journal restrictions.

Open Access This article is distributed under the terms of the Creative Commons Attribution Noncommercial License which permits any noncommercial use, distribution, and reproduction in any medium, provided the original author(s) and source are credited.

\section{References}

1. Ross RS (2004) Molecular and mechanical synergy: cross-talk between integrins and growth factor receptors. Cardiovasc Res 63:381-390

2. Bissell MJ, Labarge MA (2005) Context, tissue plasticity, and cancer: are tumor stem cells also regulated by the microenvironment? Cancer Cell 7:17-23

3. Geiger B, Spatz JP, Bershadsky AD (2009) Environmental sensing through focal adhesions. Nat Rev Mol Cell Biol 10:2133

4. Hynes RO (2009) The extracellular matrix: not just pretty fibrils. Science 326:1216-1219

5. Timpl R, Brown JC (1996) Supramolecular assembly of basement membranes. Bioessays 18:123-132

6. Yurchenco PD, Cheng YS, Campbell K, Li S (2004) Loss of basement membrane, receptor and cytoskeletal lattices in a laminin-deficient muscular dystrophy. J Cell Sci 117:735-742
7. Smyth N, Vatansever HS, Murray P, Meyer M, Frie C, Paulsson M, Edgar D (1999) Absence of basement membranes after targeting the LAMC1 gene results in embryonic lethality due to failure of endoderm differentiation. J Cell Biol 144:151-160

8. Erickson AC, Couchman JR (2000) Still more complexity in mammalian basement membranes. J Histochem Cytochem 48:1291-1306

9. Schlotzer-Schrehardt U, Dietrich T, Saito K, Sorokin L, Sasaki T, Paulsson M, Kruse FE (2007) Characterization of extracellular matrix components in the limbal epithelial stem cell compartment. Exp Eye Res 85:845-860

10. Russell AJ, Fincher EF, Millman L, Smith R, Vela V, Waterman EA, Dey CN, Guide S, Weaver VM, Marinkovich MP (2003) Alpha 6 beta 4 integrin regulates keratinocyte chemotaxis through differential GTPase activation and antagonism of alpha 3 beta 1 integrin. J Cell Sci 116:3543-3556

11. Raftopoulou M, Hall A (2004) Cell migration: Rho GTPases lead the way. Dev Biol 265:23-32

12. Hamelers IH, Olivo C, Mertens AE, Pegtel DM, van der Kammen RA, Sonnenberg A, Collard JG (2005) The Rac activator Tiam1 is required for (alpha)3(beta)1-mediated laminin-5 deposition, cell spreading, and cell migration. J Cell Biol 171:871-881

13. Sehgal BU, DeBiase PJ, Matzno S, Chew TL, Claiborne JN, Hopkinson SB, Russell A, Marinkovich MP, Jones JC (2006) Integrin beta 4 regulates migratory behavior of keratinocytes by determining laminin-332 organization. J Biol Chem 281:3548735498

14. Hamill KJ, Kligys K, Hopkinson SB, Jones JC (2009) Laminin deposition in the extracellular matrix: a complex picture emerges. J Cell Sci 122:4409-4417

15. Schofield R (1978) The relationship between the spleen colonyforming cell and the haemopoietic stem cell. Blood Cells 4:7-25

16. Daley WP, Peters SB, Larsen M (2008) Extracellular matrix dynamics in development and regenerative medicine. J Cell Sci 121:255-264

17. Spradling A, Drummond-Barbosa D, Kai T (2001) Stem cells find their niche. Nature 414:98-104

18. McMillan JR, Akiyama M, Shimizu H (2003) Epidermal basement membrane zone components: ultrastructural distribution and molecular interactions. J Dermatol Sci 31:169-177

19. Miosge N (2001) The ultrastructural composition of basement membranes in vivo. Histol Histopathol 16:1239-1248

20. Kunze A, Abari E, Semkova I, Paulsson M, Hartmann U (2009) Deposition of nidogens and other basement membrane proteins in the young and aging mouse retina. Ophthalmic Res 43:108-112

21. Kvist AJ, Nystrom A, Hultenby K, Sasaki T, Talts JF, Aspberg A (2008) The major basement membrane components localize to the chondrocyte pericellular matrix: a cartilage basement membrane equivalent? Matrix Biol 27:22-33

22. Kruegel J, Sadowski B, Miosge N (2008) Nidogen-1 and nidogen-2 in healthy human cartilage and in late-stage osteoarthritis cartilage. Arthritis Rheum 58:1422-1432

23. Tesche F, Miosge N (2004) Perlecan in late stages of osteoarthritis of the human knee joint. Osteoarthr Cartil 12:852-862

24. Yurchenco PD, Patton BL (2009) Developmental and pathogenic mechanisms of basement membrane assembly. Curr Pharm Des 15:1277-1294

25. Durbeej M (2010) Laminins. Cell Tissue Res 339:259-268

26. Miner JH (2008) Laminins and their roles in mammals. Microsc Res Tech 71:349-356

27. Khoshnoodi J, Pedchenko V, Hudson BG (2008) Mammalian collagen IV. Microsc Res Tech 71:357-370

28. Whitelock JM, Melrose J, Iozzo RV (2008) Diverse cell signaling events modulated by perlecan. Biochemistry 47:1117411183 
29. Knox SM, Whitelock JM (2006) Perlecan: how does one molecule do so many things? Cell Mol Life Sci 63:2435-2445

30. Ho MS, Bose K, Mokkapati S, Nischt R, Smyth N (2008) Nidogens: extracellular matrix linker molecules. Microsc Res Tech 71:387-395

31. Breitkreutz D, Mirancea N, Nischt R (2009) Basement membranes in skin: unique matrix structures with diverse functions? Histochem Cell Biol 132:1-10

32. Barczyk M, Carracedo S, Gullberg D (2010) Integrins. Cell Tissue Res 339:269-280

33. Loeser RF (2002) Integrins and cell signaling in chondrocytes. Biorheology 39:119-124

34. Aumailley M, Bruckner-Tuderman L, Carter WG, Deutzmann R, Edgar D, Ekblom P, Engel J, Engvall E, Hohenester E, Jones JC, Kleinman HK, Marinkovich MP, Martin GR, Mayer U, Meneguzzi G, Miner JH, Miyazaki K, Patarroyo M, Paulsson M, Quaranta V, Sanes JR, Sasaki T, Sekiguchi K, Sorokin LM, Talts JF, Tryggvason K, Uitto J, Virtanen I, von der Mark K, Wewer UM, Yamada Y, Yurchenco PD (2005) A simplified laminin nomenclature. Matrix Biol 24:326-332

35. Tzu J, Marinkovich MP (2008) Bridging structure with function: structural, regulatory, and developmental role of laminins. Int J Biochem Cell Biol 40:199-214

36. Patton BL (2000) Laminins of the neuromuscular system. Microsc Res Tech 51:247-261

37. Sasaki T, Mann K, Miner JH, Miosge N, Timpl R (2002) Domain IV of mouse laminin beta1 and beta2 chains. Eur $\mathrm{J}$ Biochem 269:431-442

38. Nishimune H, Valdez G, Jarad G, Moulson CL, Muller U, Miner JH, Sanes JR (2008) Laminins promote postsynaptic maturation by an autocrine mechanism at the neuromuscular junction. J Cell Biol 182:1201-1215

39. Sugawara K, Tsuruta D, Ishii M, Jones JC, Kobayashi H (2008) Laminin-332 and -511 in skin. Exp Dermatol 17:473-480

40. Lu W, Miyazaki K, Mizushima H, Nemoto N (2001) Immunohistochemical distribution of laminin-5 gamma2 chain and its developmental change in human embryonic and foetal tissues. Histochem J 33:629-637

41. Durr J, Lammi P, Goodman SL, Aigner T, von der Mark K (1996) Identification and immunolocalization of laminin in cartilage. Exp Cell Res 222:225-233

42. Hiraoka K, Grogan S, Olee T, Lotz M (2006) Mesenchymal progenitor cells in adult human articular cartilage. Biorheology 43:447-454

43. Dowthwaite GP, Bishop JC, Redman SN, Khan IM, Rooney P, Evans DJR, Haughton L, Bayram Z, Boyer S, Thomson B et al (2004) The surface of articular cartilage contains a progenitor cell population. J Cell Sci 117:889-897

44. Miosge N, Gunther E, Heyder E, Manshausen B, Herken R (1995) Light and electron microscopic localization of the alpha 1-chain and the E1 and E8 domains of laminin-1 in mouse kidney using monoclonal antibodies to establish the orientation of laminin-1 within basement membranes. J Histochem Cytochem 43:675-680

45. Tsiper MV, Yurchenco PD (2002) Laminin assembles into separate basement membrane and fibrillar matrices in Schwann cells. J Cell Sci 115:1005-1015

46. Jones JC, Lane K, Hopkinson SB, Lecuona E, Geiger RC, Dean DA, Correa-Meyer E, Gonzales M, Campbell K, Sznajder JI, Budinger S (2005) Laminin-6 assembles into multimolecular fibrillar complexes with perlecan and participates in mechanicalsignal transduction via a dystroglycan-dependent, integrinindependent mechanism. J Cell Sci 118:2557-2566

47. Tran M, Rousselle P, Nokelainen P, Tallapragada S, Nguyen NT, Fincher EF, Marinkovich MP (2008) Targeting a tumor- specific laminin domain critical for human carcinogenesis. Cancer Res 68:2885-2894

48. Patarroyo M, Tryggvason K, Virtanen I (2002) Laminin isoforms in tumor invasion, angiogenesis and metastasis. Semin Cancer Biol 12:197-207

49. Kariya Y, Yasuda C, Nakashima Y, Ishida K, Tsubota Y, Miyazaki K (2004) Characterization of laminin 5B and NH2terminal proteolytic fragment of its alpha3B chain: promotion of cellular adhesion, migration, and proliferation. J Biol Chem 279:24774-24784

50. Urbano JM, Torgler CN, Molnar C, Tepass U, Lopez-Varea A, Brown NH, de Celis JF, Martin-Bermudo MD (2009) Drosophila laminins act as key regulators of basement membrane assembly and morphogenesis. Development 136:4165-4176

51. Jimenez-Mallebrera C, Brown SC, Sewry CA, Muntoni F (2005) Congenital muscular dystrophy: molecular and cellular aspects. Cell Mol Life Sci 62:809-823

52. Noakes PG, Gautam M, Mudd J, Sanes JR, Merlie JP (1995) Aberrant differentiation of neuromuscular junctions in mice lacking s-laminin/laminin beta 2 . Nature 374:258-262

53. Gubler MC (2008) Inherited diseases of the glomerular basement membrane. Nat Clin Pract Nephrol 4:24-37

54. Li J, Tzu J, Chen Y, Zhang YP, Nguyen NT, Gao J, Bradley M, Keene DR, Oro AE, Miner JH, Marinkovich MP (2003) Laminin-10 is crucial for hair morphogenesis. EMBO J 22:2400 2410

55. Miner JH, Li C (2000) Defective glomerulogenesis in the absence of laminin alpha5 demonstrates a developmental role for the kidney glomerular basement membrane. Dev Biol 217:278-289

56. Pulkkinen L, Uitto J (1999) Mutation analysis and molecular genetics of epidermolysis bullosa. Matrix Biol 18:29-42

57. Di Nunzio F, Maruggi G, Ferrari S, Di Iorio E, Poletti V, Garcia M, Del Rio M, De Luca M, Larcher F, Pellegrini G, Mavilio F (2008) Correction of laminin-5 deficiency in human epidermal stem cells by transcriptionally targeted lentiviral vectors. Mol Ther 16:1977-1985

58. Knoll R, Postel R, Wang J, Kratzner R, Hennecke G, Vacaru AM, Vakeel P, Schubert C, Murthy K, Rana BK, Kube D, Knoll G, Schafer K, Hayashi T, Holm T, Kimura A, Schork N, Toliat MR, Nurnberg P, Schultheiss HP, Schaper W, Schaper J, Bos E, Den Hertog J, van Eeden FJ, Peters PJ, Hasenfuss G, Chien KR, Bakkers J (2007) Laminin-alpha4 and integrin-linked kinase mutations cause human cardiomyopathy via simultaneous defects in cardiomyocytes and endothelial cells. Circulation $116: 515-525$

59. Iozzo RV (2005) Basement membrane proteoglycans: from cellar to ceiling. Nat Rev Mol Cell Biol 6:646-656

60. Nikolova G, Strilic B, Lammert E (2007) The vascular niche and its basement membrane. Trends Cell Biol 17:19-25

61. Fuchs E (2009) Finding one's niche in the skin. Cell Stem Cell 4:499-502

62. Boonen KJ, Post MJ (2008) The muscle stem cell niche: regulation of satellite cells during regeneration. Tissue Eng Part B Rev 14:419-431

63. Roediger M, Kruegel J, Miosge N, Gersdorff N (2009) Tissue distribution of perlecan domains III and V during embryonic and fetal human development. Histol Histopathol 24:859-868

64. Iozzo RV, Zoeller JJ, Nystrom A (2009) Basement membrane proteoglycans: modulators par excellence of cancer growth and angiogenesis. Mol Cells 27:503-513

65. Nystrom A, Shaik ZP, Gullberg D, Krieg T, Eckes B, Zent R, Pozzi A, Iozzo RV (2009) Role of tyrosine phosphatase SHP-1 in the mechanism of endorepellin angiostatic activity. Blood 114:4897-4906 
66. Zoeller JJ, McQuillan A, Whitelock J, Ho SY, Iozzo RV (2008) A central function for perlecan in skeletal muscle and cardiovascular development. J Cell Biol 181:381-394

67. Giros A, Morante J, Gil-Sanz C, Fairen A, Costell M (2007) Perlecan controls neurogenesis in the developing telencephalon. BMC Dev Biol 7:29

68. Melrose J, Hayes AJ, Whitelock JM, Little CB (2008) Perlecan, the "jack of all trades" proteoglycan of cartilaginous weightbearing connective tissues. Bioessays 30:457-469

69. Manton KJ, Leong DF, Cool SM, Nurcombe V (2007) Disruption of heparan and chondroitin sulfate signaling enhances mesenchymal stem cell-derived osteogenic differentiation via bone morphogenetic protein signaling pathways. Stem Cells 25:2845-2854

70. Kvist AJ, Johnson AE, Morgelin M, Gustafsson E, Bengtsson E, Lindblom K, Aszodi A, Fässler R, Sasaki T, Timpl R, Aspberg A (2006) Chondroitin sulfate perlecan enhances collagen fibril formation: implications for perlecan chondrodysplasias. J Biol Chem 281:33127-33139

71. Bix G, Castello R, Burrows M, Zoeller JJ, Weech M, Iozzo RA, Cardi C, Thakur ML, Barker CA, Camphausen K, Iozzo RV (2006) Endorepellin in vivo: targeting the tumor vasculature and retarding cancer growth and metabolism. J Natl Cancer Inst 98:1634-1646

72. Arikawa-Hirasawa E, Le AH, Nishino I, Nonaka I, Ho NC, Francomano CA, Govindraj P, Hassell JR, Devaney JM, Spranger J, Stevenson RE, Iannaccone S, Dalakas MC, Yamada $Y$ (2002) Structural and functional mutations of the perlecan gene cause Schwartz-Jampel syndrome, with myotonic myopathy and chondrodysplasia. Am J Hum Genet 70:1368-1375

73. Rodgers KD, Sasaki T, Aszodi A, Jacenko O (2007) Reduced perlecan in mice results in chondrodysplasia resembling Schwartz-Jampel syndrome. Hum Mol Genet 16:515-528

74. Arikawa-Hirasawa E, Wilcox WR, Le AH, Silverman N, Govindraj P, Hassell JR, Yamada Y (2001) Dyssegmental dysplasia, Silverman-Handmaker type, is caused by functional null mutations of the perlecan gene. Nat Genet 27:431-434

75. Costell M, Gustafsson E, Aszodi A, Morgelin M, Bloch W, Hunziker E, Addicks K, Timpl R, Fassler R (1999) Perlecan maintains the integrity of cartilage and some basement membranes. J Cell Biol 147:1109-1122

76. Hudson BG (2004) The molecular basis of Goodpasture and Alport syndromes: beacons for the discovery of the collagen IV family. J Am Soc Nephrol 15:2514-2527

77. Poschl E, Schlotzer-Schrehardt U, Brachvogel B, Saito K, Ninomiya Y, Mayer U (2004) Collagen IV is essential for basement membrane stability but dispensable for initiation of its assembly during early development. Development 131:16191628

78. Ninomiya Y, Kagawa M, Iyama K, Naito I, Kishiro Y, Seyer JM, Sugimoto M, Oohashi T, Sado Y (1995) Differential expression of two basement membrane collagen genes, COL4A6 and COL4A5, demonstrated by immunofluorescence staining using peptide-specific monoclonal antibodies. J Cell Biol 130:1219-1229

79. Poduval P, Sillat T, Beklen A, Kouri VP, Virtanen I, Konttinen YT (2007) Type IV collagen alpha-chain composition in synovial lining from trauma patients and patients with rheumatoid arthritis. Arthritis Rheum 56:3959-3967

80. Vanacore R, Ham AJ, Voehler M, Sanders CR, Conrads TP, Veenstra TD, Sharpless KB, Dawson PE, Hudson BG (2009) A sulfilimine bond identified in collagen IV. Science 325:12301234

81. Vogel W, Brakebusch C, Fassler R, Alves F, Ruggiero F, Pawson T (2000) Discoidin domain receptor 1 is activated independently of beta(1) integrin. J Biol Chem 275:5779-5784
82. Gross O, Beirowski B, Harvey SJ, McFadden C, Chen D, Tam S, Thorner PS, Smyth N, Addicks K, Bloch W, Ninomiya Y, Sado Y, Weber M, Vogel WF (2004) DDR1-deficient mice show localized subepithelial GBM thickening with focal loss of slit diaphragms and proteinuria. Kidney Int 66:102-111

83. Aumailley M, Timpl R (1986) Attachment of cells to basement membrane collagen type IV. J Cell Biol 103:1569-1575

84. Xu J, Rodriguez D, Petitclerc E, Kim JJ, Hangai M, Moon YS, Davis GE, Brooks PC (2001) Proteolytic exposure of a cryptic site within collagen type IV is required for angiogenesis and tumor growth in vivo. J Cell Biol 154:1069-1079

85. Sudhakar A, Boosani CS (2008) Inhibition of tumor angiogenesis by tumstatin: insights into signaling mechanisms and implications in cancer regression. Pharm Res 25:27312739

86. Alamowitch S, Plaisier E, Favrole P, Prost C, Chen Z, Van Agtmael T, Marro B, Ronco P (2009) Cerebrovascular disease related to COL4A1 mutations in HANAC syndrome. Neurology 73:1873-1882

87. Saus J, Wieslander J, Langeveld JP, Quinones S, Hudson BG (1988) Identification of the Goodpasture antigen as the alpha 3(IV) chain of collagen IV. J Biol Chem 263:13374-13380

88. Gross O, Kashtan CE (2009) Treatment of Alport syndrome: beyond animal models. Kidney Int 76:599-603

89. Savige J, Liu J, Cabrera Debuc D, Handa JT, Hageman GS, Wang YY, Parkin JD, Vote B, Fassett R, Sarks S, Colville D (2009) Retinal basement membrane abnormalities and the retinopathy of Alport syndrome. Invest Ophthalmol Vis Sci. doi: 10.1167/iovs.08-3323

90. LeBleu V, Sugimoto H, Mundel TM, Gerami-Naini B, Finan E, Miller CA, Gattone VH 2nd, Lu L, Shield CF 3rd, Folkman J, Kalluri R (2009) Stem cell therapies benefit Alport syndrome. J Am Soc Nephrol 20:2359-2370

91. Timpl R, Dziadek M, Fujiwara S, Nowack H, Wick G (1983) Nidogen: a new, self-aggregating basement membrane protein. Eur J Biochem 137:455-465

92. Kohfeldt E, Sasaki T, Gohring W, Timpl R (1998) Nidogen-2: a new basement membrane protein with diverse binding properties. J Mol Biol 282:99-109

93. Fox JW, Mayer U, Nischt R, Aumailley M, Reinhardt D, Wiedemann H, Mann K, Timpl R, Krieg T, Engel J, Chu ML (1991) Recombinant nidogen consists of three globular domains and mediates binding of laminin to collagen type IV. EMBO J 10:3137-3146

94. Dziadek M (1995) Role of laminin-nidogen complexes in basement membrane formation during embryonic development. Experientia 51:901-913

95. Fleischmajer R, Schechter A, Bruns M, Perlish JS, Macdonald ED, Pan TC, Timpl R, Chu ML (1995) Skin fibroblasts are the only source of nidogen during early basal lamina formation in vitro. J Invest Dermatol 105:597-601

96. Thomas T, Dziadek M (1993) Genes coding for basement membrane glycoproteins laminin, nidogen, and collagen IV are differentially expressed in the nervous system and by epithelial, endothelial, and mesenchymal cells of the mouse embryo. Exp Cell Res 208:54-67

97. Salmivirta K, Talts JF, Olsson M, Sasaki T, Timpl R, Ekblom P (2002) Binding of mouse nidogen-2 to basement membrane components and cells and its expression in embryonic and adult tissues suggest complementary functions of the two nidogens. Exp Cell Res 279:188-201

98. Schymeinsky J, Nedbal S, Miosge N, Poschl E, Rao C, Beier DR, Skarnes WC, Timpl R, Bader BL (2002) Gene structure and functional analysis of the mouse nidogen-2 gene: nidogen- 2 is not essential for basement membrane formation in mice. Mol Cell Biol 22:6820-6830 
99. Miosge N, Sasaki T, Timpl R (2002) Evidence of nidogen-2 compensation for nidogen-1 deficiency in transgenic mice. Matrix Biol 21:611-621

100. Bader BL, Smyth N, Nedbal S, Miosge N, Baranowsky A, Mokkapati S, Murshed M, Nischt R (2005) Compound genetic ablation of nidogen 1 and 2 causes basement membrane defects and perinatal lethality in mice. Mol Cell Biol 25:6846-6856

101. Bose K, Nischt R, Page A, Bader BL, Paulsson M, Smyth N (2006) Loss of nidogen-1 and -2 results in syndactyly and changes in limb development. J Biol Chem 281:39620-39629

102. Gersdorff N, Otto S, Roediger M, Kruegel J, Miosge N (2007) The absence of one or both nidogens does not alter basement membrane composition in adult murine kidney. Histol Histopathol 22:1077-1084

103. Mokkapati S, Baranowsky A, Mirancea N, Smyth N, Breitkreutz D, Nischt R (2008) Basement membranes in skin are differently affected by lack of nidogen 1 and 2. J Invest Dermatol 128:2259-2267

104. Fox MA, Ho MS, Smyth N, Sanes JR (2008) A synaptic nidogen: developmental regulation and role of nidogen-2 at the neuromuscular junction. Neural Dev 3:24

105. Ackley BD, Kang SH, Crew JR, Suh C, Jin Y, Kramer JM (2003) The basement membrane components nidogen and type XVIII collagen regulate organization of neuromuscular junctions in Caenorhabditis elegans. J Neurosci 23:3577-3587

106. Dedhar S, Jewell K, Rojiani M, Gray V (1992) The receptor for the basement membrane glycoprotein entactin is the integrin alpha 3/beta 1. J Biol Chem 267:18908-18914

107. Dong LJ, Hsieh JC, Chung AE (1995) Two distinct cell attachment sites in entactin are revealed by amino acid substitutions and deletion of the RGD sequence in the cysteine-rich epidermal growth factor repeat 2. J Biol Chem 270:1583815843

108. Dong L, Chen Y, Lewis M, Hsieh JC, Reing J, Chaillet JR, Howell CY, Melhem M, Inoue S, Kuszak JR, DeGeest K, Chung AE (2002) Neurologic defects and selective disruption of basement membranes in mice lacking entactin-1/nidogen-1. Lab Invest 82:1617-1630

109. Vasudevan A, Ho MS, Weiergraber M, Nischt R, Schneider T, Lie A, Smyth N, Kohling R (2009) Basement membrane protein nidogen-1 shapes hippocampal synaptic plasticity and excitability. Hippocampus. doi:10.1002/hipo.20660

110. Lebel SP, Chen Y, Gingras D, Chung AE, Bendayan M (2003) Morphofunctional studies of the glomerular wall in mice lacking entactin-1. J Histochem Cytochem 51:1467-1478

111. Baranowsky A, Mokkapati S, Bechtel M, Krugel J, Miosge N, Wickenhauser C, Smyth N, Nischt R (2010) Impaired wound healing in mice lacking the basement membrane protein nidogen 1. Matrix Biol 29:15-21

112. Ekblom P, Ekblom M, Fecker L, Klein G, Zhang HY, Kadoya Y, Chu ML, Mayer U, Timpl R (1994) Role of mesenchymal nidogen for epithelial morphogenesis in vitro. Development 120:2003-2014

113. Mayer U, Zimmermann K, Mann K, Reinhardt D, Timpl R, Nischt R (1995) Binding properties and protease stability of recombinant human nidogen. Eur J Biochem 227:681-686

114. Kuk C, Gunawardana CG, Soosaipillai A, Kobayashi H, Li L, Zheng Y, Diamandis EP (2009) Nidogen-2: A new serum biomarker for ovarian cancer. Clin Biochem. doi:10.1016/j. clinbiochem.2009.10.012

115. Rossi DJ, Jamieson CH, Weissman IL (2008) Stems cells and the pathways to aging and cancer. Cell 132:681-696

116. Watt FM, Hogan BL (2000) Out of Eden: stem cells and their niches. Science 287:1427-1430

117. Muffler S, Stark HJ, Amoros M, Falkowska-Hansen B, Boehnke K, Buhring HJ, Marme A, Bickenbach JR, Boukamp P (2008) A stable niche supports long-term maintenance of human epidermal stem cells in organotypic cultures. Stem Cells 26:25062515

118. Fuchs E, Tumbar T, Guasch G (2004) Socializing with the neighbors: stem cells and their niche. Cell 116:769-778

119. Scheele S, Nystrom A, Durbeej M, Talts JF, Ekblom M, Ekblom P (2007) Laminin isoforms in development and disease. J Mol Med 85:825-836

120. Li L, Xie T (2005) Stem cell niche: structure and function. Annu Rev Cell Dev Biol 21:605-631

121. Moore KA, Lemischka IR (2006) Stem cells and their niches. Science 311:1880-1885

122. Kerever A, Schnack J, Vellinga D, Ichikawa N, Moon C, Arikawa-Hirasawa E, Efird JT, Mercier F (2007) Novel extracellular matrix structures in the neural stem cell niche capture the neurogenic factor fibroblast growth factor 2 from the extracellular milieu. Stem Cells 25:2146-2157

123. Otonkoski T, Banerjee M, Korsgren O, Thornell LE, Virtanen I (2008) Unique basement membrane structure of human pancreatic islets: implications for beta-cell growth and differentiation. Diabetes Obes Metab 10(Suppl 4):119-127

124. Morrison SJ, Kimble J (2006) Asymmetric and symmetric stemcell divisions in development and cancer. Nature 441:10681074

125. van Laake LW, van Donselaar EG, Monshouwer-Kloots J, Schreurs C, Passier R, Humbel BM, Doevendans PA, Sonnenberg A, Verkleij AJ, Mummery CL (2010) Extracellular matrix formation after transplantation of human embryonic stem cellderived cardiomyocytes. Cell Mol Life Sci 67:277-290

126. Evseenko D, Schenke-Layland K, Dravid G, Zhu Y, Hao QL, Scholes J, Wang XC, Maclellan WR, Crooks GM (2009) Identification of the critical extracellular matrix proteins that promote human embryonic stem cell assembly. Stem Cells Dev 18:919-928

127. Vuoristo S, Virtanen I, Takkunen M, Palgi J, Kikkawa Y, Rousselle P, Sekiguchi K, Tuuri T, Otonkoski T (2008) Laminin isoforms in human embryonic stem cells: Synthesis, receptor usage and growth support. J Cell Mol Med. doi:10.1111/j. 1582-4934.2008.00643.x

128. Dellatore SM, Garcia AS, Miller WM (2008) Mimicking stem cell niches to increase stem cell expansion. Curr Opin Biotechnol 19:534-540

129. Bajanca F, Luz M, Raymond K, Martins GG, Sonnenberg A, Tajbakhsh S, Buckingham M, Thorsteinsdottir S (2006) Integrin alpha6beta1-laminin interactions regulate early myotome formation in the mouse embryo. Development 133:1635-1644

130. Blaess S, Graus-Porta D, Belvindrah R, Radakovits R, Pons S, Littlewood-Evans A, Senften M, Guo H, Li Y, Miner JH, Reichardt LF, Muller U (2004) Beta1-integrins are critical for cerebellar granule cell precursor proliferation. J Neurosci 24:3402-3412

131. Fujiwara H, Hayashi Y, Sanzen N, Kobayashi R, Weber CN, Emoto T, Futaki S, Niwa H, Murray P, Edgar D, Sekiguchi K (2007) Regulation of mesodermal differentiation of mouse embryonic stem cells by basement membranes. J Biol Chem 282:29701-29711

132. Xu C, Inokuma MS, Denham J, Golds K, Kundu P, Gold JD, Carpenter MK (2001) Feeder-free growth of undifferentiated human embryonic stem cells. Nat Biotechnol 19:971-974

133. Greenlee AR, Kronenwetter-Koepel TA, Kaiser SJ, Liu K (2005) Comparison of Matrigel and gelatin substrata for feederfree culture of undifferentiated mouse embryonic stem cells for toxicity testing. Toxicol In Vitro 19:389-397

134. Coucouvanis E, Martin GR (1995) Signals for death and survival: a two-step mechanism for cavitation in the vertebrate embryo. Cell 83:279-287 
135. Murray P, Edgar D (2000) Regulation of programmed cell death by basement membranes in embryonic development. J Cell Biol 150:1215-1221

136. Zeisberg M, Bonner G, Maeshima Y, Colorado P, Muller GA, Strutz F, Kalluri R (2001) Renal fibrosis: collagen composition and assembly regulates epithelial-mesenchymal transdifferentiation. Am J Pathol 159:1313-1321

137. Sahai E, Marshall CJ (2002) RHO-GTPases and cancer. Nat Rev Cancer 2:133-142

138. Mathias RA, Chen YS, Wang B, Ji H, Kapp EA, Moritz RL, Zhu HJ, Simpson RJ (2010) Extracellular remodelling during oncogenic Ras-induced epithelial-mesenchymal transition facilitates MDCK cell migration. J Proteome Res 9:1007-1019

139. Levayer R, Lecuit T (2008) Breaking down EMT. Nat Cell Biol 10:757-759

140. Rowe RG, Weiss SJ (2008) Breaching the basement membrane: who, when and how? Trends Cell Biol 18:560-574

141. Yang J, Mani SA, Donaher JL, Ramaswamy S, Itzykson RA, Come C, Savagner P, Gitelman I, Richardson A, Weinberg RA (2004) Twist, a master regulator of morphogenesis, plays an essential role in tumor metastasis. Cell 117:927-939

142. Barrallo-Gimeno A, Nieto MA (2005) The Snail genes as inducers of cell movement and survival: implications in development and cancer. Development 132:3151-3161

143. Poincloux R, Lizarraga F, Chavrier P (2009) Matrix invasion by tumour cells: a focus on MT1-MMP trafficking to invadopodia. J Cell Sci 122:3015-3024

144. Ulazzi L, Sabbioni S, Miotto E, Veronese A, Angusti A, Gafa R, Manfredini S, Farinati F, Sasaki T, Lanza G, Negrini M (2007) Nidogen 1 and 2 gene promoters are aberrantly methylated in human gastrointestinal cancer. Mol Cancer 6:17

145. Maruyama S, Cheng J, Yamazaki M, Zhou XJ, Zhang ZY, He RG, Saku T (2010) Metastasis-associated genes in oral squamous cell carcinoma and salivary adenoid cystic carcinoma: a differential DNA chip analysis between metastatic and nonmetastatic cell systems. Cancer Genet Cytogenet 196:14-22

146. de Bernabe DB, Inamori K, Yoshida-Moriguchi T, Weydert CJ, Harper HA, Willer T, Henry MD, Campbell KP (2009) Loss of alpha-dystroglycan laminin binding in epithelium-derived cancers is caused by silencing of LARGE. J Biol Chem 284:11279-11284

147. Kariya Y, Mori T, Yasuda C, Watanabe N, Kaneko Y, Nakashima Y, Ogawa T, Miyazaki K (2008) Localization of laminin alpha3B chain in vascular and epithelial basement membranes of normal human tissues and its down-regulation in skin cancers. J Mol Histol 39:435-446

148. Takkunen M, Ainola M, Vainionpaa N, Grenman R, Patarroyo M, Garcia de Herreros A, Konttinen YT, Virtanen I (2008) Epithelial-mesenchymal transition downregulates laminin alpha5 chain and upregulates laminin alpha4 chain in oral squamous carcinoma cells. Histochem Cell Biol 130:509-525

149. Kulasekara KK, Lukandu OM, Neppelberg E, Vintermyr OK, Johannessen AC, Costea DE (2009) Cancer progression is associated with increased expression of basement membrane proteins in three-dimensional in vitro models of human oral cancer. Arch Oral Biol 54:924-931

150. Ryschich E, Khamidjanov A, Kerkadze V, Buchler MW, Zoller M, Schmidt J (2009) Promotion of tumor cell migration by extracellular matrix proteins in human pancreatic cancer. Pancreas 38:804-810

151. Tsuruta D, Kobayashi H, Imanishi H, Sugawara K, Ishii M, Jones JC (2008) Laminin-332-integrin interaction: a target for cancer therapy? Curr Med Chem 15:1968-1975

152. Bilde A, von Buchwald C, Dabelsteen E, Therkildsen MH, Dabelsteen S (2009) Molecular markers in the surgical margin of oral carcinomas. J Oral Pathol Med 38:72-78
153. Legate KR, Wickstrom SA, Fassler R (2009) Genetic and cell biological analysis of integrin outside-in signaling. Genes Dev 23:397-418

154. von der Mark K, Park J, Bauer S, Schmuki P (2010) Nanoscale engineering of biomimetic surfaces: cues from the extracellular matrix. Cell Tissue Res 339:131-153

155. Blanpain C, Fuchs E (2009) Epidermal homeostasis: a balancing act of stem cells in the skin. Nat Rev Mol Cell Biol 10:207-217

156. Owens DM, Watt FM (2003) Contribution of stem cells and differentiated cells to epidermal tumours. Nat Rev Cancer $3: 444-451$

157. Hashimoto J, Kariya Y, Miyazaki K (2006) Regulation of proliferation and chondrogenic differentiation of human mesenchymal stem cells by laminin-5 (laminin-332). Stem Cells 24:2346-2354

158. Guasch G, Schober M, Pasolli HA, Conn EB, Polak L, Fuchs E (2007) Loss of TGFbeta signaling destabilizes homeostasis and promotes squamous cell carcinomas in stratified epithelia. Cancer Cell 12:313-327

159. Jones PH, Watt FM (1993) Separation of human epidermal stem cells from transit amplifying cells on the basis of differences in integrin function and expression. Cell 73:713-724

160. Li A, Simmons PJ, Kaur P (1998) Identification and isolation of candidate human keratinocyte stem cells based on cell surface phenotype. Proc Natl Acad Sci USA 95:3902-3907

161. Boonen KJ, Rosaria-Chak KY, Baaijens FP, van der Schaft DW, Post MJ (2009) Essential environmental cues from the satellite cell niche: optimizing proliferation and differentiation. Am J Physiol Cell Physiol 296:C1338-C1345

162. DiMario JX, Stockdale FE (1995) Differences in the developmental fate of cultured and noncultured myoblasts when transplanted into embryonic limbs. Exp Cell Res 216:431-442

163. Blau HM, Brazelton TR, Weimann JM (2001) The evolving concept of a stem cell: entity or function? Cell 105:829-841

164. Sherwood RI, Wagers AJ (2006) Harnessing the potential of myogenic satellite cells. Trends Mol Med 12:189-192

165. Grossi A, Yadav K, Lawson MA (2007) Mechanical stimulation increases proliferation, differentiation and protein expression in culture: stimulation effects are substrate dependent. J Biomech 40:3354-3362

166. Macfelda K, Kapeller B, Wilbacher I, Losert UM (2007) Behavior of cardiomyocytes and skeletal muscle cells on different extracellular matrix components-relevance for cardiac tissue engineering. Artif Organs 31:4-12

167. Colognato H, Winkelmann DA, Yurchenco PD (1999) Laminin polymerization induces a receptor-cytoskeleton network. J Cell Biol 145:619-631

168. Wilschut KJ, Haagsman HP, Roelen BA (2009) Extracellular matrix components direct porcine muscle stem cell behavior. Exp Cell Res. doi:10.1016/j.yexcr.2009.10.014

169. Boontheekul T, Hill EE, Kong HJ, Mooney DJ (2007) Regulating myoblast phenotype through controlled gel stiffness and degradation. Tissue Eng 13:1431-1442

170. Yao CC, Ziober BL, Sutherland AE, Mendrick DL, Kramer RH (1996) Laminins promote the locomotion of skeletal myoblasts via the alpha 7 integrin receptor. J Cell Sci 109(Pt 13):31393150

171. Baharvand H, Azarnia M, Parivar K, Ashtiani SK (2005) The effect of extracellular matrix on embryonic stem cell-derived cardiomyocytes. J Mol Cell Cardiol 38:495-503

172. Leri A, Kajstura J, Anversa P, Frishman WH (2008) Myocardial regeneration and stem cell repair. Curr Probl Cardiol 33:91-153

173. Helbling-Leclerc A, Zhang X, Topaloglu H, Cruaud C, Tesson F, Weissenbach J, Tomé FM, Schwartz K, Fardeau M, Tryggvason $\mathrm{K}$ et al (1995) Mutations in the laminin alpha 2-chain 
gene (LAMA2) cause merosin-deficient congenital muscular dystrophy. Nat Genet 11:216-218

174. Malan D, Reppel M, Dobrowolski R, Roell W, Smyth N, Hescheler J, Paulsson M, Bloch W, Fleischmann BK (2009) Lack of laminin gammal in embryonic stem cell-derived cardiomyocytes causes inhomogeneous electrical spreading despite intact differentiation and function. Stem Cells 27:88-99

175. Herpel E, Singer S, Flechtenmacher C, Pritsch M, Sack FU, Hagl S, Katus HA, Haass M, Otto HF, Schnabel PA (2005) Extracellular matrix proteins and matrix metalloproteinases differ between various right and left ventricular sites in endstage cardiomyopathies. Virchows Arch 446:369-378

176. Shamhart PE, Meszaros JG (2009) Non-fibrillar collagens: Key mediators of post-infarction cardiac remodeling? J Mol Cell Cardiol. doi:10.1016/j.yjmcc.2009.06.017

177. Carmeliet P (2003) Blood vessels and nerves: common signals, pathways and diseases. Nat Rev Genet 4:710-720

178. Lammert E, Cleaver O, Melton D (2001) Induction of pancreatic differentiation by signals from blood vessels. Science 294:564567

179. Shen Q, Goderie SK, Jin L, Karanth N, Sun Y, Abramova N, Vincent P, Pumiglia K, Temple S (2004) Endothelial cells stimulate self-renewal and expand neurogenesis of neural stem cells. Science 304:1338-1340

180. Christov C, Chretien F, Abou-Khalil R, Bassez G, Vallet G, Authier FJ, Bassaglia Y, Shinin V, Tajbakhsh S, Chazaud B, Gherardi RK (2007) Muscle satellite cells and endothelial cells: close neighbors and privileged partners. Mol Biol Cell 18:13971409

181. Stratman AN, Malotte KM, Mahan RD, Davis MJ, Davis GE (2009) Pericyte recruitment during vasculogenic tube assembly stimulates endothelial basement membrane matrix formation. Blood 114:5091-5101

182. Yamashita J, Itoh H, Hirashima M, Ogawa M, Nishikawa S, Yurugi T, Naito M, Nakao K, Nishikawa S (2000) Flk1-positive cells derived from embryonic stem cells serve as vascular progenitors. Nature 408:92-96

183. Fisher M (2009) Pericyte signaling in the neurovascular unit. Stroke 40:S13-S15

184. Paquet-Fifield S, Schluter H, Li A, Aitken T, Gangatirkar P, Blashki D, Koelmeyer R, Pouliot N, Palatsides M, Ellis S, Brouard N, Zannettino A, Saunders N, Thompson N, Li J, Kaur P (2009) A role for pericytes as microenvironmental regulators of human skin tissue regeneration. J Clin Invest 119:2795-2806

185. Caplan AI (2008) All MSCs are pericytes? Cell Stem Cell 3:229-230

186. Lozito TP, Kuo CK, Taboas JM, Tuan RS (2009) Human mesenchymal stem cells express vascular cell phenotypes upon interaction with endothelial cell matrix. J Cell Biochem 107:714-722

187. Philp D, Chen SS, Fitzgerald W, Orenstein J, Margolis L, Kleinman HK (2005) Complex extracellular matrices promote tissue-specific stem cell differentiation. Stem Cells 23:288-296

188. Suzuki S, Narita Y, Yamawaki A, Murase Y, Satake M, Mutsuga M, Okamoto H, Kagami H, Ueda M, Ueda Y (2009) Effects of extracellular matrix on differentiation of human bone marrow-derived mesenchymal stem cells into smooth muscle cell lineage: utility for cardiovascular tissue engineering. Cells Tissues Organs. doi:10.1159/000260061

189. Phinney DG, Prockop DJ (2007) Concise review: mesenchymal stem/multipotent stromal cells: the state of transdifferentiation and modes of tissue repair-current views. Stem Cells 25:28962902

190. Caplan AI, Dennis JE (2006) Mesenchymal stem cells as trophic mediators. J Cell Biochem 98:1076-1084

191. Frosch KH, Drengk A, Krause P, Viereck V, Miosge N, Werner C, Schild D, Sturmer EK, Sturmer KM (2006) Stem cell-coated titanium implants for the partial joint resurfacing of the knee. Biomaterials 27:2542-2549

192. Toma C, Wagner WR, Bowry S, Schwartz A, Villanueva F (2009) Fate of culture-expanded mesenchymal stem cells in the microvasculature: in vivo observations of cell kinetics. Circ Res 104:398-402

193. Potapova IA, Gaudette GR, Brink PR, Robinson RB, Rosen MR, Cohen IS, Doronin SV (2007) Mesenchymal stem cells support migration, extracellular matrix invasion, proliferation, and survival of endothelial cells in vitro. Stem Cells 25:1761-1768

194. Chen XD, Dusevich V, Feng JQ, Manolagas SC, Jilka RL (2007) Extracellular matrix made by bone marrow cells facilitates expansion of marrow-derived mesenchymal progenitor cells and prevents their differentiation into osteoblasts. J Bone Miner Res 22:1943-1956

195. Xiao Q, Zeng L, Zhang Z, Hu Y, Xu Q (2007) Stem cell-derived Sca-1+ progenitors differentiate into smooth muscle cells, which is mediated by collagen IV-integrin alpha1/beta1/alphav and PDGF receptor pathways. Am J Physiol Cell Physiol 292:C342-C352

196. Sanders MA, Basson MD (2000) Collagen IV-dependent ERK activation in human Caco-2 intestinal epithelial cells requires focal adhesion kinase. J Biol Chem 275:38040-38047

197. Klees RF, Salasznyk RM, Vandenberg S, Bennett K, Plopper GE (2007) Laminin-5 activates extracellular matrix production and osteogenic gene focusing in human mesenchymal stem cells. Matrix Biol 26:106-114

198. Nakagawa T, Lee SY, Reddi AH (2009) Induction of chondrogenesis from human embryonic stem cells without embryoid body formation by bone morphogenetic protein 7 and transforming growth factor beta1. Arthritis Rheum 60:3686-3692

199. Koelling S, Kruegel J, Irmer M, Path JR, Sadowski B, Miro X, Miosge N (2009) Migratory chondrogenic progenitor cells from repair tissue during the later stages of human osteoarthritis. Cell Stem Cell 4:324-335

200. Miosge N, Gunther E, Becker-Rabbenstein V, Herken R (1993) Ultrastructural localization of laminin subunits during the onset of mesoderm formation in the mouse embryo. Anat Embryol (Berl) 187:601-605

201. Miosge N, Heinemann S, Leissling A, Klenczar C, Herken R (1999) Ultrastructural triple localization of laminin-1, nidogen1 , and collagen type IV helps elucidate basement membrane structure in vivo. Anat Rec 254:382-388 